\title{
Discovery of compounds that inhibit SARS-CoV-2 Mac1-ADP-ribose binding by high- throughput screening
} Wazir $^{\mathrm{e}}$, Dana Ferraris ${ }^{\mathrm{f}}$, Lari Lehtiö ${ }^{\mathrm{e}}$, Anthony K.L. Leung ${ }^{\mathrm{d}}$, Anthony R. Fehr ${ }^{\mathrm{b}, \#}$

*These authors contributed equally to this work

anfectious Disease Assay Development Laboratory/HTS, University of Kansas, Lawrence, Kansas 66047, USA

${ }^{b}$ Department of Molecular Biosciences, University of Kansas, Lawrence, Kansas 66045, USA

$12{ }^{\mathrm{c}}$ Molecular Graphics and Modeling Laboratory and the Computational Chemical Biology Core,

13 University of Kansas, Lawrence, Kansas 66047, USA

14 department of Biochemistry and Molecular Biology, Bloomberg School of Public Health, Johns Hopkins

15 University, Baltimore, Maryland 21205, USA

$16{ }^{\mathrm{e}}$ Faculty of Biochemistry and Molecular Medicine \& Biocenter Oulu, University of Oulu, Oulu, Finland

$17{ }^{\mathrm{f}}$ McDaniel College Department of Chemistry, 2 College Hill, Westminster, MD ${ }^{\mathrm{a}} \mathrm{McD}$ aniel College,

18 Westminister, MD 21157

\#Correspondence: arfehr@ku.edu; Tel.: +1- (785) 864-6626 (K.S.)

24 Keywords: Coronavirus, SARS-CoV-2, macrodomain, ADP-ribose, ADP-ribosylation, high-

25 throughput screening 


\section{ABSTRACT}

27 The emergence of several zoonotic viruses in the last twenty years, especially the

28 pandemic outbreak of SARS-CoV-2, has exposed a dearth of antiviral drug therapies for viruses

29 with pandemic potential. Developing a diverse drug portfolio will be critical for our ability to

30 rapidly respond to novel coronaviruses (CoVs) and other viruses with pandemic potential. Here

31 we focus on the SARS-CoV-2 conserved macrodomain (Mac1), a small domain of non-structural

32 protein 3 (nsp3). Mac1 is an ADP-ribosylhydrolase that cleaves mono-ADP-ribose (MAR) from

33 target proteins, protects the virus from the anti-viral effects of host ADP-ribosyltransferases, and

34 is critical for the replication and pathogenesis of CoVs. In this study, a luminescent-based high-

35 throughput assay was used to screen $\sim 38,000$ small molecules for those that could inhibit Mac1-

36 ADP-ribose binding. We identified 5 compounds amongst 3 chemotypes that inhibit SARS-CoV-

372 Mac1-ADP-ribose binding in multiple assays with $\mathrm{IC}_{50}$ values less than $100 \mu \mathrm{M}$, inhibit ADP-

38 ribosylhydrolase activity, and have evidence of direct Mac1 binding. These chemotypes are

39 strong candidates for further derivatization into highly effective Mac1 inhibitors. 


\section{INTRODUCTION}

COVID-19, caused by severe acute respiratory syndrome coronavirus 2 (SARS-CoV-2),

42 is one of the most disruptive and deadly pandemics in modern times, with greater than 385

43 million cases and having led to greater than 5.7 million deaths worldwide. SARS-CoV-2 is the

44 third $\mathrm{CoV}$ to emerge into the human population in the last 3 decades, following outbreaks of

45 SARS-CoV in 2002-2003 and Middle East respiratory syndrome MERS-CoV in 2012. These

46 outbreaks highlight the potential for $\mathrm{CoVs}$ to cross-species barriers and cause severe disease in a

47 new host. There is a tremendous need to develop broad-spectrum antiviral therapies capable of

48 targeting a wide range of CoVs to prevent severe disease following zoonotic outbreaks.

50 from two polyproteins, 1a and 1ab (ppla and pplab) (1). The largest non-structural protein is

51 non-structural protein 3 (nsp3) that encodes for multiple modular protein domains. Both the

52 SARS-CoV and the SARS-CoV-2 nsp3 proteins include three tandem macrodomains, Mac1,

$53 \mathrm{Mac}$, and Mac3 (2). Mac1 is present in all CoVs, unlike Mac2 and Mac3, and contains a

54 conserved three-layered $\alpha / \beta / \alpha$ fold, a common feature amongst all macrodomains. All CoV Mac1

55 proteins tested have mono-ADP-ribosylhydrolase (ARH) activity, though it remains unclear if

56 they have significant poly-ARH activity (3-8). In contrast, Mac2 and Mac3 fail to bind ADP-

57 ribose and instead bind to nucleic acids $(9,10)$. Mac1 homologs are also found in alphaviruses,

58 Hepatitis E virus, and Rubella virus, indicating that ADP-ribosylation may be a potent anti-viral

59 post-translational modification (PTM) $(11,12)$. All are members of the larger MacroD-type

60 macrodomain family, which includes human macrodomains Mdo1 and Mdo2 (13).

61 ADP-ribosylation is a post-translational modification catalyzed by ADP-

62 ribosyltransferases (ARTs, also known as PARPs) through transferring an ADP-ribose moiety 
63 from $\mathrm{NAD}^{+}$onto target proteins or nucleic acids (14). ADP-ribose is transferred in as a single

64 unit as mono-ADP-ribose (MAR), or it is transferred consecutively and covalently attached

65 through glycosidic bonds to preceding ADP-ribose units to form a poly-ADP-ribose (PAR)

66 chain. Both mono- and poly-ARTs inhibit virus replication, implicating ADP-ribosylation in the

67 host-response to infection (15).

68 Several reports have addressed the role of Mac1 on the replication and pathogenesis of

69 CoVs, mostly using the mutation of a highly conserved asparagine to alanine (N41A-SARS-

$70 \mathrm{CoV}$ ). This mutation abolished the MAR-hydrolase activity of SARS-CoV Mac1 (16). This

71 mutation has minimal effects on $\mathrm{CoV}$ replication in transformed cells, but reduces viral load,

72 leads to enhanced IFN production, and strongly attenuates both murine hepatitis virus (MHV)

73 and SARS-CoV in mouse models of infection (4,16-18). Murine hepatitis virus strain JHM

74 (MHV-JHM) Mac1 was also required for efficient replication in primary macrophages, which

75 could be partially rescued by the PARP inhibitors or siRNA knockdown of PARP12 or PARP14

76 (19). These data suggest that Mac1's function is to counter PARP-mediated anti-viral ADP-

77 ribosylation (20). More recently, we have identified mutations in the MHV-JHM Mac1 domain,

78 predicted to abolish ADP-ribose binding, that resulted in severe replication defects in cell

79 culture, indicating that for some CoVs Mac1 may be even more important than previously

80 appreciated (21). Mutations in the alphavirus and HEV macrodomain also have substantial

81 phenotypic effects on virus replication and pathogenesis (22-26).

82 As viral macrodomains are critical virulence factors, they are unique targets for anti-viral

83 therapeutics (20). Several studies have reported structures that could potentially bind to the ADP-

84 ribose binding pocket of SARS-CoV-2 Mac1. While most of these studies were limited to in

85 silico studies, a few have tested compound activity in biochemical assays, but have been met 
86 with minimal success (27-30). The only compounds identified thus far that inhibit SARS-CoV-2

87 Mac1 with $\mathrm{IC}_{50}$ less than $100 \mu \mathrm{M}$ are Suramin, which inhibited Mac1-ADP-ribose binding in a

88 FRET assay with an $\mathrm{IC}_{50}$ of $8.7 \mu \mathrm{M}$, and Dasatanib, which inhibited Mac1 mono-ARH activity

89 with an $\mathrm{IC}_{50}$ of $\sim 50 \mu \mathrm{M}$. Suramin targeted several divergent macrodomains and is known to have

90 additional targets, and thus is not suitable for further evaluation (30). Dasatinib is not a candidate

91 for a Mac1 inhibitor as it is toxic to mammalian cells, though it may provide a scaffold for

92 further inhibitor development. None of the identified compounds have been tested for their

93 ability to inhibit Mac1 in cell culture or in animal models of disease.

94 Here, we optimized two high-throughput macrodomain-ADP-ribose binding assays, a

95 previously described luminescent-based AlphaScreen ${ }^{\mathrm{TM}}$ assay, and a novel fluorescence

96 polarization assay $(31,32)$, and used the AlphaScreen ${ }^{\mathrm{TM}}$ assay to screen $\sim 38,000$ compounds for

97 their ability to inhibit SARS-CoV-2 Mac1-ADP-ribose binding. We identified 5 compounds

98 from 3 chemotypes that inhibited ADP-ribose binding by the SARS-CoV-2 Mac1 protein in both

99 assays, some with $\mathrm{IC}_{50}$ values as low as 5-10 $\mu \mathrm{M}$. These compounds also demonstrated some

100 inhibition of ARH activity and have evidence of direct binding to Mac1. The profiling of the

101 most potent inhibitor against a panel of virus and human MAR binding and hydrolyzing proteins

102 revealed the remarkable selectivity of the inhibition of SARS-CoV-2 Mac1. These compounds

103 represent several series that can be further developed into potent Mac1 inhibitors and potential

104 therapeutics for SARS-CoV-2 and other CoVs of interest.

105

106 RESULTS and DISCUSSION

107 Comparison of viral and human macrodomains in two high-throughput ADP-ribose

108 binding assays. Here we established two distinct ADP-ribose binding assays for multiple 
macrodomain proteins (Fig. 1A-C). First, we adopted a previously published AlphaScreen ${ }^{\mathrm{TM}}$

110 (AS) assay, where a short peptide was modified at a leucine residue with ADP-ribose through an

111 amino-oxyacetic acid linkage, and at a second leucine residue with biotin (Fig. 1A) (32).

112 Streptavidin donor beads and $\mathrm{Ni}^{2+}$ acceptor beads induce a light signal if the His-tagged Mac1

113 protein interacts with the biotinylated peptide (Fig. 1B). We also developed a fluorescent

114 polarization (FP) assay as an orthogonal assay to evaluate interactions of macrodomains with

115 ADP-ribosylated peptide. This assay used the same peptide but with fluorescein attached instead

116 of biotin and measures polarization of the fluorescent signal (Fig. 1C). We then tested 4 separate

117 macrodomains for their ability to bind to these peptides, the human macrodomain Mdo2, and

118 Mac1 from SARS-CoV, MERS-CoV, and SARS-CoV-2. All 4 macrodomains bound to the

119 ADP-ribosylated control peptides better than to non-ADP-ribosylated peptides (Fig. 1D,G). The

120 AS assay had an especially strong signal-to-background ratio, ranging from $\sim 0.75-2 \times 10^{3}$. To

121 further study the binding of Mac1 proteins to AS and FP peptides, we evaluated binding in a

122 dose-dependent assay. Of these four proteins, the human MDO2 demonstrated the highest

123 affinity in both assays, with a $\mathrm{K}_{\mathrm{D}}$ of $1.1 \pm 0.3 \mu \mathrm{M}$ in the FP assay and reached a maximum signal

124 in the AS assay at $40 \mathrm{nM}$ (Fig. 1E,H). The SARS-CoV-2 Mac1 had a $\mathrm{K}_{\mathrm{D}}$ of $3.4 \pm 0.4 \mu \mathrm{M}$ in the

125 FP assay and reached a maximum signal in the AS assay at $0.625 \mu \mathrm{M}$, while the SARS-CoV and

126 MERS-CoV Macl both reached their maximum signal in the AS assay at $\sim 1.25-2.5 \mu \mathrm{M}$ (AS)

127 and had $\mathrm{K}_{\mathrm{D}}$ 's of $7.7 \pm 1.3 \mu \mathrm{M}$ and $19.9 \pm 3.3 \mu \mathrm{M}$ in the FP assay, respectively (Fig. 1F,I).

128 Next, we tested the ability of free ADP-ribose to inhibit the binding of Mac1 to the ADP-

129 ribosylated peptide. For these displacement assays, the amount of beads, peptide, and Mac1

130 protein amounts to be used were optimized to obtain a robust signal while limiting the amount of

131 reagents used for screening purposes (see Methods). The addition of free ADP-ribose, but not 
132 ATP, into the AS and FP assays inhibited human macrodomain and CoV Mac1 binding to the

133 ADP-ribosylated peptides, confirming that these assays can be used to identify macrodomain

134 binding inhibitors (Fig. 2). $\mathrm{IC}_{50}$ values for free ADP-ribose ranged between $0.24 \mu \mathrm{M}$ with SARS-

$135 \mathrm{CoV}$ Mac1 to $1.5 \mu \mathrm{M}$ with SARS-CoV-2 using the free ADP-ribose in the AS assay (Fig. 2A).

136 Similar results, albeit higher $\mathrm{IC}_{50}$ values were observed in the FP assay, likely because of higher

137 amount of Mac1 used in this assay $(4 \mu \mathrm{M}$ vs $250 \mathrm{nM})$, with $\mathrm{IC}_{50}$ values ranging from $2.3 \mu \mathrm{M}$ to

$1389.74 \mu \mathrm{M}$ (Fig. 2B).

140 High-throughput screening (HTS) for SARS-CoV-2 Mac1 inhibitors. We next performed a

141 small pilot screen of $\sim 2,000$ compounds from the Maybridge Mini Library of drug-like scaffolds

142 at $10 \mu \mathrm{M}$ using both AS and FP assays (Fig. 3A-B). We identified 39 compounds that

143 significantly inhibited Mac1-ADP-ribose binding at $>3$ standard deviations (3SD) plus the plate

144 median (Fig. 3A-B). After performing dose-response curves we found that two compounds

145 inhibited binding in both assays (Fig. 4A). We then tested these compounds in a counter screen,

146 which is also an AS assay that utilizes a biotinylated-His peptide that gives off a strong signal

147 with the addition of streptavidin donor and nickel acceptor beads. These two compounds did not

148 affect the signal from our counter screen indicating that they do not intrinsically inhibit the assay.

149 After this initial validation of our screen, three additional libraries were chosen to include a total

150 number of 35,863 compounds from the Analyticon, 3D BioDiversity, and Peptidomimetics

151 libraries (Fig. 3A). We chose the AS assay as our primary HTS assay, as the average Z' score for

152 the AS was higher than the Z' score from the FP assay in our original screen (0.82 vs 0.67$)$. In

153 this larger screen, the average $Z^{\prime}$ was $0.89 \pm 0.05$, indicating a strong separation between positive

154 and negative controls (Fig. 3C). Using the same hit criteria described above for each individual 
155 library, we identified 406 hits resulting in a 1\% hit rate (Fig. 3D). Of note, the Analyticon library

156 produced a lot of non-specific inhibitors, indicating a lot of these compounds likely inhibit the

157 assays themselves (Fig. 3B). We next performed dose-response (10-40 $\mu \mathrm{M})$ curves of these 406

158 compounds in our primary (AS), orthogonal (FP), and counter screen (Bn-His6) assays (Fig. 3).

159 From the 406 original hits, 26 compounds were identified that inhibited SARS-CoV-2 Mac1-

160 ADP-ribose binding in the AS assay in a dose-dependent fashion, and 6 compounds were

161 identified that inhibited Mac1 binding in both AS and FP assays (Fig. 3D). Of these 32 hit

162 compounds, we re-purchased 17 of them, excluding 15 based on several selection criteria,

163 including substantial inhibition of the counter screen, high $\mathrm{IC}_{50}$ values in the AlphaScreen, pan-

164 assay interference compounds, and compound availability (Fig. 3D). The remaining 17

165 compounds along with 4 analogs were repurchased or resynthesized (see Methods).

166 Re-purchased compounds were evaluated in dose-response assays against both SARS-

167 CoV-2 Mac1 and human MDO2 protein. Our cutoff criteria included: $i$ ) compound must inhibit 168 both primary and orthogonal assays with at least $75 \%$ inhibition in AS assay and at or near $50 \%$

169 inhibition in the FP assay, and ii) less than 30\% inhibition of the Bn-His 6 counter screen. Among

170 the 17 selected and the 4 analogs compounds, six compounds inhibited ADP-ribose binding of

171 SARS-CoV-2 Mac1 in both AS and FP assays with no substantial inhibition of the Bn-His6

172 counter screen. These were compounds $\mathbf{1 , 2 , 6 , 7 , 1 0}$, and 11 (Table 1). IC 50 values ranged from 6.2

$173 \mu \mathrm{M}$ to $112.2 \mu \mathrm{M}$ in AS assay and 7.3 $\mu \mathrm{M}$ to $159.4 \mu \mathrm{M}$ in FP assay (Table 1, Fig. 4). Compounds

$174 \mathbf{1}, \mathbf{1 0}$, and 11 also had some inhibitory activity against the MERS-CoV Mac1 protein, though the

175 inhibition of MERS-CoV Mac1 was lower than the inhibition demonstrated against SARS-CoV-

1762 (Table 1). In addition, only compound 2 inhibited MDO2, indicating that these compounds

177 were broadly specific for viral macrodomains. 
Selected compounds demonstrate evidence of SARS-CoV-2 Mac 1 binding. Next, we set out

to test the hypothesis that these compounds inhibit Mac1-ADP-ribose by binding to Mac1, and

181 not other components of the assay, such as the peptide. To test for Mac1 binding, we used a

182 differential scanning fluorimetry (DSF) assay as previously described (8) and tested our top 6 hit

183 compounds (Fig. 5, S1) and compounds 8 and 9, as they are analogs of 6 and 7 (Fig. S2). In this

184 assay, compound binding to Mac1 should increase the melting temperature of Mac1. The

185 addition of free ADP-ribose, which binds to Mac1, showed a dose-dependent increase of

186 approximately $4^{\circ} \mathrm{C}$ in the melting temperature of Mac1, while the negative control, ATP, had no

187 effect, as previously demonstrated (8). 1, 6, 7, 10, and 11 showed dose-dependent shifts in the

188 melting temperature of Mac1 ranging from $0.2-1.5^{\circ} \mathrm{C}$, providing strong evidence that these

189 compounds bind to Mac1, albeit not with the same affinity as ADP-ribose. On the other hand,

190 compound 2 resulted in highly irregular thermal shift curves, indicating that this compound may

191 not be a true Mac1 binder (Fig. 5, S1). These results provide evidence that 5 of our 6 hit

192 compounds $(\mathbf{1}, \mathbf{6}, \mathbf{7}, \mathbf{1 0}$, and $\mathbf{1 1})$ directly bind to SARS-CoV-2 Mac1.

194 Hit compounds inhibit ADP-ribosylhydrolase activity in vitro. SARS-CoV-2 Mac1 is a

195 mono-ADP-ribosylhydrolase that removes mono-ADP-ribose from target proteins (8). Next, we

196 examined the ability of some of our top 5 hit compounds to inhibit the enzymatic activity of

197 SARS-CoV-2 Mac1 using two distinct assays. The first approach was a gel-based Mac1 ADP-

198 ribosylhydrolase assay where we tested each compound against the SARS-CoV-2 Mac1 protein

199 (8). Compound 1 tended to precipitate in these assays at higher concentrations, and so we used

200 lower concentrations for this compound than others. Compounds 1, 6, and 7 exhibited a dose- 
201 dependent inhibition of Mac1 ADP-ribosylhydrolase activity (Fig. 6A). We were unable to detect 202 any significant inhibition with $\mathbf{1 0}$ and $\mathbf{1 1}$ in this assay.

203 Next, we utilized a recently published high-throughput luminescence-based ADP-

204 ribosylhydrolyase assay (33). Here we found that 1, 6, 7, 10 and 11 all showed dose-dependent

205 inhibition of ADP-ribosylhydrolase activity (Fig. 6B). 6 was clearly the most efficient inhibitor,

206 as it had a peak of $\sim 60 \%$ inhibition, similar to Dasatinib which we previously identified in a

207 separate HTS (33). In contrast to the gel-based assay, 10 and $\mathbf{1 1}$ did inhibit ADP-

208 ribosylhydrolase activity in this assay, likely reflecting the increased sensitivity of this assay

209 compared to the gel-based assay. These results indicate that the identified Mac1 inhibitors block

210 Mac1 binding and Mac1 enzymatic activity.

212 Selectivity Profiling. As compound 6 inhibited both Mac1 ADP-ribose binding and hydrolysis

213 activity, and showed the strongest evidence of direct Mac1 binding, we tested its ability to inhibit

21416 different macrodomains using a recently developed FRET-based assay (30). Again, 6

215 demonstrated dose-dependent inhibition of Mac1-ADP-ribose binding in this assay, consistent

216 with our AS results but with a slightly higher $\mathrm{IC}_{50}$ of $45.0 \pm 10.9 \mu \mathrm{M}$ (Fig. 7A). Remarkably,

217 when tested again 16 different human and viral macrodomains in this assay, 6 only inhibited

218 SARS-CoV-2 Mac1, having only minimal levels in inhibition of all other macrodomain proteins,

219 including other CoV macrodomains (Fig. 7B), which is in agreement with the selectivity

220 observed in AS (Table 1). These results indicate that this compound is highly selective for the

221 SARS-CoV-2 Mac1 protein. 
223 Structure activity relationship (SAR). The top 5 compounds could be separated into 3

224 chemotypes based on their structures. To analyze the involved residues and type of connection

225 between selected hit compound and Mac1, we used computational docking analysis to get an

226 initial structure activity relationship (SAR) by predicting poses of compounds in Mac1

227 structures. In addition to our 5 hit compounds, we also docked compounds $\mathbf{8}$ and $\mathbf{9}$ as they are

228 analogs of $\mathbf{6}$ and 7 and could give further insight into SAR, even though we either detected

229 minimal or no direct Mac1 binding by these compounds. These seven compounds were docked

230 against the ADP-ribose bound structure of SARS-CoV-2 Mac1 (PDB 6WOJ) as well as three apo

231 structures of Mac1 were used (PDB 7KR0, 7KR1, 6WEY). Docking and glide emodel scores

232 were calculated for each compound against all four structures and the best structure was chosen

233 based on these scores (Table S1). Analog compounds 6, 7, 8, and 9 were assessed both based on

234 score and visual inspection, and were re-docked using a core constraint to a high scoring,

235 intuitive pose of compound 7. All top scoring poses were subsequently minimized using Prime,

236 allowing flexibility within $5 \AA$ of the ligand. Compound 1 was its own chemotype but has a

237 sulfonohydrazide that is also found in a compound identified in a previous screen for Mac1

238 compounds (34). It also has a thienopyrimidine that is similar to the pyrrolopyrimidine found in

239 of the compounds identified in the fragment screen by Schuller et al (31). It makes a hydrogen

240 bond with a backbone amine of D22, pie-stacking interactions with F156, and extends with a

241 benzene ring into the distal ribose pocket inserting in between the GGG and GIF loops (Fig. 8A).

242 Compounds $\mathbf{1 0}$ and $\mathbf{1 1}$ are close analogs with a single difference of positioning in the

243 bromobenzoyl moiety on the piperidine ring (Fig. 4C). These compounds had similar activity

244 across the board in our assays, making it difficult to analyze their SAR. While they docked into

245 the binding pocket, these docking poses only indicate a single hydrogen bond with the backbone 
246 amino of D22. In contrast, compounds 6, 7, 8, and 9 are close analogs of each other and have a

247 wide-range of inhibitory and binding activity. $\mathrm{IC}_{50}$ values for these compounds range from 10 to

248 several hundred $\mu \mathrm{M}$ (Table 1). Direct binding also varied substantially, with $\mathrm{T}_{\mathrm{m}}$ 's ranging from

$249 \sim 1.7^{\circ} \mathrm{C}(\mathbf{6})$ to undetectable binding (8). These compounds all have the same base structure,

250 including a beta-alanine core substituted with a N-benzyl or N-chlorobenzyl group, a methoxy

251 benzoyl group and a piperazine amide. The main difference between $\mathbf{6}$ and its analogs are the

252 addition of a methoxy group on the benzoyl group (7), the loss of a chlorine (8), and a missing

253 methoxy group (9). Each of these changes reduces the activity of this series indicating that $i$ ) the

254 orientation of the methoxy groups on 6 is likely important for its increased activity, $i$ )

255 reorienting 7 to accommodate the 4-methoxy group likely decreases activity due to the disruption

256 of multiple interactions, and $\mathrm{iii}$ ) the chlorine likely makes a critical halogen bond with a

257 backbone amino group of L126 in the binding pocket.

258 In conclusion, we developed multiple high-throughput ADP-ribose binding assays and

259 performed HTS to identify high-quality Mac1 inhibitors. We followed these screens with several

260 additional assays to measure their ability to inhibit ADP-ribosylhydrolase activity and their direct

261 binding to Mac1. We have identified 5 compounds that inhibit both the primary and orthogonal

262 assays without inhibiting the counter screen and demonstrate dose-dependent inhibition of Mac1

263 enzymatic activity. Compounds $\mathbf{1}$ and $\mathbf{6}$ are particularly effective with $\mathrm{IC}_{50}$ values of $\sim 10 \mu \mathrm{M}$ in

264 the AS assay, along with thermal shifts and docking poses that indicate direct binding to Mac1.

265 Compound 6 shows excellent selectivity towards SARS-CoV-2 over the human macrodomains

266 guiding further development of the compound. We expect that these compounds could be

267 utilized for further derivatization and optimization into more potent Mac1 inhibitors. 


\section{METHODS}

\section{Reagents}

All plasmids and proteins used were expressed and purified as previously described

271 (30,35-37). All compounds were repurchased from MolPort except for compounds $\mathbf{6}$ and $\mathbf{1 0}$,

272 which were repurchased from ChemDiv. After reordering once, compounds $\mathbf{1 0}$ and $\mathbf{1 1}$ became

273 unavailable and thus were resynthesized according to the literature (38). ADP-ribosylated

274 peptides were purchased from Cambridge peptides.

\section{Differential Scanning Fluorimetry (DSF)}

277 Diagnostics). In total, a $15 \mu \mathrm{L}$ mixture containing $8 X$ SYPRO Orange (Invitrogen), and $10 \mu \mathrm{M}$

278 macrodomain protein in buffer containing $20 \mathrm{mM}$ HEPES, $\mathrm{NaOH}, \mathrm{pH} 7.5$ and various

279 concentrations of ADP-ribose or hit compounds were mixed on ice in 384-well PCR plate

280 (Roche). Fluorescent signals were measured from 25 to $95^{\circ} \mathrm{C}$ in $0.2{ }^{\circ} \mathrm{C} / 30 / \mathrm{Sec}$ steps (excitation,

$281470-505 \mathrm{~nm}$; detection, 540-700 nm). The main measurements were carried out in triplicate. Data

282 evaluation and $\mathrm{T}_{\mathrm{m}}$ determination involved use of the Roche LightCycler ${ }^{\circledR} 480$ Protein Melting

283 Analysis software, and data fitting calculations involved the use of single site binding curve

284 analysis on GraphPad Prism. The thermal shift $\left(\Delta \mathrm{T}_{\mathrm{m}}\right)$ was calculated by subtracting the $\mathrm{T}_{\mathrm{m}}$

285 values of the DMSO from the $\mathrm{T}_{\mathrm{m}}$ values of compounds.

\section{AlphaScreen (AS) Assay}

287 The AlphaScreen reactions were carried out in 384-well plates (Alphaplate, PerkinElmer,

288 Waltham, MA) in a total volume of $40 \mu \mathrm{L}$ in buffer containing $25 \mathrm{mM}$ HEPES (pH 7.4), 100

$289 \mathrm{mM} \mathrm{NaCl}, 0.5 \mathrm{mM}$ TCEP, $0.1 \% \mathrm{BSA}$, and $0.05 \%$ CHAPS. All reagents were prepared as $4 \mathrm{X}$

290 stocks and $10 \mu \mathrm{L}$ volume of each reagent was added to a final volume of $40 \mu \mathrm{L}$. All compounds 
291 were transferred acoustically using ECHO 555 (Beckman Inc) and preincubated after mixing

292 with purified His-tagged macrodomain protein $(250 \mathrm{nM})$ for $30 \mathrm{~min}$ at RT, followed by addition

293 of a 10 amino acid biotinylated and ADP-ribosylated peptide [ARTK(Bio)QTARK(Aoa-

294 RADP)S] (Cambridge peptides) (625 nM). After $1 \mathrm{~h}$ incubation at RT, streptavidin-coated donor

295 beads $(7.5 \mu \mathrm{g} / \mathrm{mL})$ and nickel chelate acceptor beads $(7.5 \mu \mathrm{g} / \mathrm{mL})$; (PerkinElmer AlphaScreen

296 Histidine Detection Kit) were added under low light conditions, and plates were shaken at 400

$297 \mathrm{rpm}$ for $60 \mathrm{~min}$ at RT protected from light. Plates were kept covered and protected from light at

298 all steps and read on BioTek plate reader using an AlphaScreen 680 excitation/570 emission

299 filter set. For counter screening of the compounds, $25 \mathrm{nM}$ biotinylated and hexahistidine-tagged

300 linker peptide (Bn-His 6 ) (PerkinElmer) was added to the compounds, followed by addition of

301 beads as described above.

302 Fluorescence Polarization (FP) Assay

303 The FP assay was performed in buffer containing $25 \mathrm{mM}$ Tris $\mathrm{pH} 7.5, \mathrm{NaCl} 50 \mathrm{mM}$,

$3040.025 \%$ TritonX-100. All reagents were prepared as $2 \mathrm{X}$ stocks and $10 \mu \mathrm{L}$ volume of each reagent

305 was added to a final volume of $20 \mu \mathrm{L}$. Compounds were preincubated with His-Macrodomain

306 proteins $(4 \mu \mathrm{M})$ for 30', RT in black 384 well plates (Corning 3575 plates), followed by addition

307 of $50 \mathrm{nM}$ of fluorescein labeled ADP-ribosylated peptide [5Flu-ARTKQTARK(Aoa-RADP)S].

308 After mixing for a minute, the plate was incubated at $25^{\circ} \mathrm{C}$, protected from light and fluorescence

309 polarization was read after 30 minutes, $1 \mathrm{~h}$ and $2 \mathrm{~h}$ using a plate reader.

310 Gel-based Inhibition of Mono-ADP-ribosylhydrolase activity (de-MARylaion)

311 PARP10-CD protein was auto-MARylated through incubation for 20 minutes at $37^{\circ} \mathrm{C}$

312 with $1 \mathrm{mM}$ final concentration of $\beta$-Nicotinamide Adenine Dinucleotide $\left(\beta \mathrm{NAD}^{+}\right)$(Millipore-

313 Sigma) in a reaction buffer (50 mM HEPES, $150 \mathrm{mM} \mathrm{NaCl}, 0.2 \mathrm{mM}$ DTT, and 0.02\% NP-40). 
314 MARylated PARP10 was aliquoted and stored at $-80^{\circ} \mathrm{C}$. To test the ability of identified

315 compounds for their ability to inhibit MARylation activity of Mac1, we first incubated each

316 compound with purified SARS-CoV-2 Mac1 in the reaction buffer (50 mM HEPES, $150 \mathrm{mM}$

$317 \mathrm{NaCl}, 0.2 \mathrm{mM}$ DTT, and $0.02 \% \mathrm{NP}-40$ ) at $37^{\circ} \mathrm{C}$ for $30 \mathrm{~min}$. Then, MARylated PARP10-CD was

318 added to this mixture solution and further incubated for $30 \mathrm{~min}$ at $37^{\circ} \mathrm{C}$. The reaction was

319 stopped with addition of 2X Laemmli sample buffer containing 10\% $\beta$-mercaptoethanol. Protein

320 samples were heated at $95^{\circ} \mathrm{C}$ for 5 minutes before loading and separated onto SDS-PAGE

321 cassette (Thermo Fisher Scientific Bolt ${ }^{\mathrm{TM}}$ 4-12\% Bis-Tris Plus Gels) in MES running buffer. For

322 immunoblotting, the separated proteins were transferred onto polyvinylidene difluoride (PVDF)

323 membrane using iBlot ${ }^{\mathrm{TM}} 2$ Dry Blotting System (ThermoFisher Scientific). The blot was blocked

324 with 5\% skim milk in 1xPBS and probed with the anti-mono-ADP-ribose binding

325 reagent/antibody MABE1076 ( $\alpha$-MAR), and anti-GST tag monoclonal antibody MA4-004

326 (ThermoFisher Scientific). The primary antibodies were detected with secondary anti-rabbit and

327 anti-mouse antibodies (LI-COR Biosciences). All immunoblots were visualized using

328 Odyssey ${ }^{\circledR}$ CLx Imaging System (LI-COR Biosciences). The images were quantitated using the

329 LI-COR Image Studio software.

330 ADP-ribosylhydrolase assay

331 The recently published assay, ADPr-Glo, was used to examine the impact of our top hit

332 compounds on SARS-CoV-2 enzymatic activity (33). Briefly, the compounds were preincubated

333 with SARS-CoV-2 Mac1 $(2 \mathrm{nM})$ and NudF $(125 \mathrm{nM})$ at ambient temperature for 30 min prior to

334 the addition of MARylated PARP-10 derived substrate. The substrate $(20 \mu \mathrm{M})$ was then

335 incubated with the SARS-CoV-2 Mac1 and NudF at ambient temperature for $30 \mathrm{~min}$. The

336 reaction products were measured with AMP-Glo. Reactions without macrodomains were 
337 performed in parallel as a negative control. Luminescence signal was converted to AMP

338 concentration via interpolation from an AMP standard curve. Data plotted are AMP generated by

339 the macrodomain and NudF, subtracted by AMP generated from NudF alone. Inhibition

340 percentages were calculated and non-linear regression analysis was performed in GraphPad

341 Prism.

\section{A FRET based binding assay and inhibitor profiling}

343

FRET method was utilized for the profiling of MCD-628 a panel of human and viral

344 macrodomains to determine their specificity $(30,36)$. The assay is based on the site-specific

345 introduction of cysteine-linked mono-ADP-ribose to the C-terminal Gai peptide (GAP) by

346 Pertussis toxin subunit1 (PtxS1) fused to YFP. To generate the FRET signal ADP-ribosyl binders

347 were fused to CFP. Samples were prepared in the assay buffer (for most binders; $10 \mathrm{mM}$ Bis-

348 Tris propane $\mathrm{pH} 7.0,3 \%$ (w/v) PEG 20,000, $0.01 \%(\mathrm{v} / \mathrm{v})$ Triton X-100 and $0.5 \mathrm{mM}$ TCEP), (for

349 TARG1; $10 \mathrm{mM}$ Bis-Tris propane $\mathrm{pH}$ 7.0, $150 \mathrm{mM} \mathrm{NaCl}, 0.01 \%(\mathrm{v} / \mathrm{v})$ Triton X-100 and 0.5

$350 \mathrm{mM}$ TCEP), (for PARG; $10 \mathrm{mM}$ Bis-Tris propane $\mathrm{pH}$ 7.0, $25 \mathrm{mM} \mathrm{NaCl,} 0.01$ \% (v/v) Triton X-

351100 and $0.5 \mathrm{mM}$ TCEP) in a 384-well black polypropylene flat-bottom plates (Greiner, Bio-one)

352 with $10 \mu \mathrm{L}$ reaction volume per well. The reactions consisted of $1 \mu \mathrm{M}$ CFP-fused binders and 5

$353 \mu$ M MARylated YFP-GAP. Reactions were excited at $410 \mathrm{~nm}$ (20 nm bandwidth), while the

354 emission signal was measured at $477 \mathrm{~nm}$ (10 $\mathrm{nm}$ bandwidth) and $527 \mathrm{~nm}$ (10 $\mathrm{nm}$ bandwidth).

355 Afterwards, blank was deducted from the individual values and the radiometric FRET (rFRET)

356 was calculated by dividing the fluorescence intensities at $527 \mathrm{~nm}$ by $477 \mathrm{~nm}$. Compound was

357 dispensed with Echo acoustic liquid dispenser (Labcyte, Sunnyvate, CA). Dispensing of larger

358 volumes of the solutions was carried out by using Microfluidic Liquid Handler (MANTIS ${ }$, 
359 Formulatrix, Beford, MA, USA). Measurements were taken with Tecan Infinite M1000 pro plate

360 reader.

\section{Computational modeling}

362 Hit compounds were docked into the ADPr-bound (6WOJ), 3 unique unbound

363 conformations (7KR0, 7KR1, 6WEY) and two small molecule bound (5RSG, 5RTT) structures

364 of SARS-CoV-2 Mac1 $(35,39,40)$. The proteins and ligands were prepared using Schrodinger

365 Maestro and were subsequently docked using Glide with XP precision, analog compounds 6, 7,

$366 \mathbf{8}$, and 9 were re-docked using a core constraint to a high scoring, intuitive pose of compound 7 ,

367 and high scoring poses were subjected to a Prime MM-GBSA minimization, allowing flexibility

368 for any residue within $5 \AA$ of the ligand (41-46). 


\section{ACKNOWLEDGEMENTS}

370 ARF would like to the the KU Synthetic Chemistry Core facility for help in ordering and

371 confirming several of these compounds. DVF would like to acknowledge McDaniel College

372 Student-Faculty Summer Research Fund, the Jean Richards Fund, the Schofield fund, and the

373 Scott and Natalie Dahne fund. DVF would also like to acknowledge Mr. Kristopher Mason and

374 Vaccitech for the use of their mass spectrometer. LL would like to acknowledge the use of the

375 facilities of the Biocenter Oulu Structural Biology core facility, a member of Biocenter Finland,

376 Instruct-ERIC Centre Finland and FINStruct. This research was funded by National Institutes of

377 Health (NIH) grants P20 GM113117, P30GM110761, a CTSA grant from NCATS awarded to

378 the University of Kansas for Frontiers: University of Kansas Clinical and Translational Science

379 Institute (\#UL1TR002366), and University of Kansas start-up funds to ARF, and by Sidrid

380 Jusélius foundation grant to LL, and Johns Hopkins Bloomberg School of Public Health

381 Discretionary Fund to AKLL. The contents are solely the responsibility of the authors and do not

382 necessarily represent the official views of the NIH or NCATS. 


\section{REFERENCES}

384 1. Fehr, A. R., and Perlman, S. (2015) Coronaviruses: An Overview of Their Replication

2. Srinivasan, S., Cui, H., Gao, Z., Liu, M., Lu, S., Mkandawire, W., Narykov, O., Sun, M., and Korkin, D. (2020) Structural Genomics of SARS-CoV-2 Indicates Evolutionary Conserved Functional Regions of Viral Proteins. Viruses 12, 360

3. Egloff, M. P., Malet, H., Putics, A., Heinonen, M., Dutartre, H., Frangeul, A., Gruez, A., Campanacci, V., Cambillau, C., Ziebuhr, J., Ahola, T., and Canard, B. (2006) Structural and functional basis for ADP-ribose and poly(ADP-ribose) binding by viral macro domains. J Virol 80, 8493-8502

4. Putics, A., Filipowicz, W., Hall, J., Gorbalenya, A. E., and Ziebuhr, J. (2005) ADPribose-1"-monophosphatase: a conserved coronavirus enzyme that is dispensable for viral replication in tissue culture. J Virol 79, 12721-12731

5. Saikatendu, K. S., Joseph, J. S., Subramanian, V., Clayton, T., Griffith, M., Moy, K., Velasquez, J., Neuman, B. W., Buchmeier, M. J., Stevens, R. C., and Kuhn, P. (2005) Structural basis of severe acute respiratory syndrome coronavirus ADP-ribose-1"phosphate dephosphorylation by a conserved domain of nsP3. Structure 13, 1665-1675

6. Cho, C. C., Lin, M. H., Chuang, C. Y., and Hsu, C. H. (2016) Macro Domain from Middle East Respiratory Syndrome Coronavirus (MERS-CoV) Is an Efficient ADPribose Binding Module: CRYSTAL STRUCTURE AND BIOCHEMICAL STUDIES. $J$ Biol Chem 291, 4894-4902

7. Xu, Y. Y., Cong, L., Chen, C., Wei, L., Zhao, Q., Xu, X. L., Ma, Y. L., Bartlam, M., and Rao, Z. H. (2009) Crystal Structures of Two Coronavirus ADP-Ribose-1 "Monophosphatases and Their Complexes with ADP-Ribose: a Systematic Structural Analysis of the Viral ADRP Domain. Journal of Virology 83, 1083-1092

8. Alhammad, Y. M. O., Kashipathy, M. M., Roy, A., Gagne, J. P., McDonald, P., Gao, P., Nonfoux, L., Battaile, K. P., Johnson, D. K., Holmstrom, E. D., Poirier, G. G., Lovell, S., and Fehr, A. R. (2021) The SARS-CoV-2 Conserved Macrodomain Is a Mono-ADPRibosylhydrolase. J. Virol. 95, e01969-01920

9. Tan, J., Vonrhein, C., Smart, O. S., Bricogne, G., Bollati, M., Kusov, Y., Hansen, G., Mesters, J. R., Schmidt, C. L., and Hilgenfeld, R. (2009) The SARS-Unique Domain (SUD) of SARS Coronavirus Contains Two Macrodomains That Bind G-Quadruplexes. PLoS Path. 5, e1000428

10. Chatterjee, A., Johnson, M. A., Serrano, P., Pedrini, B., Joseph, J. S., Neuman, B. W., Saikatendu, K., Buchmeier, M. J., Kuhn, P., and Wüthrich, K. (2009) Nuclear magnetic resonance structure shows that the severe acute respiratory syndrome coronavirus-unique domain contains a macrodomain fold. Journal of virology 83, 1823-1836

11. Makrynitsa, G. I., Ntonti, D., Marousis, K. D., Birkou, M., Matsoukas, M. T., Asami, S., Bentrop, D., Papageorgiou, N., Canard, B., Coutard, B., and Spyroulias, G. A. (2019) Conformational plasticity of the VEEV macro domain is important for binding of ADPribose. J Struct Biol 206, 119-127

12. Malet, H., Coutard, B., Jamal, S., Dutartre, H., Papageorgiou, N., Neuvonen, M., Ahola, T., Forrester, N., Gould, E. A., Lafitte, D., Ferron, F., Lescar, J., Gorbalenya, A. E., de Lamballerie, X., and Canard, B. (2009) The crystal structures of Chikungunya and 
Venezuelan equine encephalitis virus nsP3 macro domains define a conserved adenosine binding pocket. $J$ Virol $\mathbf{8 3}, 6534-6545$

13. Rack, J. G., Perina, D., and Ahel, I. (2016) Macrodomains: Structure, Function, Evolution, and Catalytic Activities. Annu Rev Biochem 85, 431-454

14. Kim, D. S., Challa, S., Jones, A., and Kraus, W. L. (2020) PARPs and ADP-ribosylation in RNA biology: from RNA expression and processing to protein translation and proteostasis. Genes Dev. 34, 302-320

15. Fehr, A. R., Singh, S. A., Kerr, C. M., Mukai, S., Higashi, H., and Aikawa, M. (2020) The impact of PARPs and ADP-ribosylation on inflammation and host-pathogen interactions. Genes Dev 34, 341-359

16. Fehr, A. R., Channappanavar, R., Jankevicius, G., Fett, C., Zhao, J., Athmer, J., Meyerholz, D. K., Ahel, I., and Perlman, S. (2016) The Conserved Coronavirus Macrodomain Promotes Virulence and Suppresses the Innate Immune Response during Severe Acute Respiratory Syndrome Coronavirus Infection. mBio 7, e 01721-01716

17. Eriksson, K. K., Cervantes-Barragan, L., Ludewig, B., and Thiel, V. (2008) Mouse hepatitis virus liver pathology is dependent on ADP-ribose-1"-phosphatase, a viral function conserved in the alpha-like supergroup. J Virol 82, 12325-12334

18. Fehr, A. R., Athmer, J., Channappanavar, R., Phillips, J. M., Meyerholz, D. K., and Perlman, S. (2015) The nsp3 macrodomain promotes virulence in mice with coronavirusinduced encephalitis. J Virol 89, 1523-1536

19. Grunewald, M. E., Chen, Y., Kuny, C., Maejima, T., Lease, R., Ferraris, D., Aikawa, M., Sullivan, C. S., Perlman, S., and Fehr, A. R. (2019) The coronavirus macrodomain is required to prevent PARP-mediated inhibition of virus replication and enhancement of IFN expression. PLoS Pathog 15, e1007756

20. Alhammad, Y. M. O., and Fehr, A. R. (2020) The Viral Macrodomain Counters Host Antiviral ADP-Ribosylation. Viruses 12, 384

21. Voth, L. S., O’Connor, J. J., Kerr, C. M., Doerger, E., Schwarting, N., Sperstad, P.,
Johnson, D. K., and Fehr, A. R. (2021) Unique mutations in the MHV macrodomain differentially attenuate virus replication, indicating multiple roles for the macrodomain in coronavirus replication. Journal of Virology, JVI. 00766-00721

22. Abraham, R., Hauer, D., McPherson, R. L., Utt, A., Kirby, I. T., Cohen, M. S., Merits, A., Leung, A. K. L., and Griffin, D. E. (2018) ADP-ribosyl-binding and hydrolase activities of the alphavirus nsP3 macrodomain are critical for initiation of virus replication. Proc Natl Acad Sci U S A 115, E10457-E10466

23. Abraham, R., McPherson, R. L., Dasovich, M., Badiee, M., Leung, A. K. L., and Griffin, D. E. (2020) Both ADP-Ribosyl-Binding and Hydrolase Activities of the Alphavirus nsP3 Macrodomain Affect Neurovirulence in Mice. mBio 11

24. McPherson, R. L., Abraham, R., Sreekumar, E., Ong, S. E., Cheng, S. J., Baxter, V. K., Kistemaker, H. A., Filippov, D. V., Griffin, D. E., and Leung, A. K. (2017) ADPribosylhydrolase activity of Chikungunya virus macrodomain is critical for virus replication and virulence. Proc Natl Acad Sci U S A 114, 1666-1671

25. Li, C., Debing, Y., Jankevicius, G., Neyts, J., Ahel, I., Coutard, B., and Canard, B. (2016) Viral Macro Domains Reverse Protein ADP-Ribosylation. J Virol 90, 8478-8486

26. Parvez, M. K. (2015) The hepatitis E virus ORF1 'X-domain' residues form a putative macrodomain protein/Appr-1"-pase catalytic-site, critical for viral RNA replication. Gene 
27. Schuller, M., Correy, G. J., Gahbauer, S., Fearon, D., Wu, T., Díaz, R. E., Young, I. D., Martins, L. C., Smith, D. H., and Schulze-Gahmen, U. (2021) Fragment binding to the Nsp3 macrodomain of SARS-CoV-2 identified through crystallographic screening and

28. Virdi, R. S., Bavisotto, R. V., Hopper, N. C., Vuksanovic, N., Melkonian, T. R., Silvaggi, N. R., and Frick, D. N. (2020) Discovery of drug-like ligands for the Mac1 domain of SARS-CoV-2 Nsp3. SLAS DISCOVERY: Advancing the Science of Drug Discovery 25, $1162-1170$

29. Russo, L. C., Tomasin, R., Matos, I. A., Manucci, A. C., Sowa, S. T., Dale, K., Caldecott, K. W., Lehtiö, L., Schechtman, D., and Meotti, F. C. (2021) The SARS-CoV-2 Nsp3 macrodomain reverses PARP9/DTX3L-dependent ADP-ribosylation induced by interferon signalling. bioRxiv

30. Sowa, S. T., Galera-Prat, A., Wazir, S., Alanen, H. I., Maksimainen, M. M., and Lehtio, L. (2021) A molecular toolbox for ADP-ribosyl binding proteins. Cell Rep Methods, 100121

31. Schuller, M., Correy, G. J., Gahbauer, S., Fearon, D., Wu, T., Diaz, R. E., Young, I. D., Carvalho Martins, L., Smith, D. H., Schulze-Gahmen, U., Owens, T. W., Deshpande, I., Merz, G. E., Thwin, A. C., Biel, J. T., Peters, J. K., Moritz, M., Herrera, N., Kratochvil, H. T., Consortium, Q. S. B., Aimon, A., Bennett, J. M., Brandao Neto, J., Cohen, A. E., Dias, A., Douangamath, A., Dunnett, L., Fedorov, O., Ferla, M. P., Fuchs, M. R., GorrieStone, T. J., Holton, J. M., Johnson, M. G., Krojer, T., Meigs, G., Powell, A. J., Rack, J. G. M., Rangel, V. L., Russi, S., Skyner, R. E., Smith, C. A., Soares, A. S., Wierman, J. L., Zhu, K., O'Brien, P., Jura, N., Ashworth, A., Irwin, J. J., Thompson, M. C., Gestwicki, J. E., von Delft, F., Shoichet, B. K., Fraser, J. S., and Ahel, I. (2021) Fragment binding to the Nsp3 macrodomain of SARS-CoV-2 identified through crystallographic screening and computational docking. $S c i A d v$, eabf8711

32. Schuller, M., Riedel, K., Gibbs-Seymour, I., Uth, K., Sieg, C., Gehring, A. P., Ahel, I., Bracher, F., Kessler, B. M., Elkins, J. M., and Knapp, S. (2017) Discovery of a Selective Allosteric Inhibitor Targeting Macrodomain 2 of Polyadenosine-Diphosphate-Ribose Polymerase 14. ACS Chem Biol 12, 2866-2874

33. Dasovich, M., Zhuo, J., Goodman, J. A., Thomas, A., McPherson, R. L., Jayabalan, A. K., Busa, V. F., Cheng, S. J., Murphy, B. A., Redinger, K. R., Alhammad, Y. M. O., Fehr, A. R., Tsukamoto, T., Slusher, B. S., Bosch, J., Wei, H., and Leung, A. K. L. (2022) High-Throughput Activity Assay for Screening Inhibitors of the SARS-CoV-2 Mac1 Macrodomain. ACS Chem Biol 17, 17-23

34. Ekblad, T., Verheugd, P., Lindgren, A. E., Nyman, T., Elofsson, M., and Schuler, H. (2018) Identification of Poly(ADP-Ribose) Polymerase Macrodomain Inhibitors Using an AlphaScreen Protocol. SLAS Discov 23, 353-362

35. Alhammad, Y. M. O., Kashipathy, M. M., Roy, A., Gagne, J. P., McDonald, P., Gao, P., Nonfoux, L., Battaile, K. P., Johnson, D. K., Holmstrom, E. D., Poirier, G. G., Lovell, S., and Fehr, A. R. (2021) The SARS-CoV-2 Conserved Macrodomain Is a Mono-ADPRibosylhydrolase. $J$ Virol 95

36. Sowa, S. T., Galera-Prat, A., Wazir, S., Alanen, H. I., Maksimainen, M. M., and Lehtio, L. (2022) Preparation of screening assays for ADP-ribosyl readers and erasers using the GAP-tag as a binding probe. STAR Protoc 3, 101147 
37. Dasovich, M., Zhuo, J., Goodman, J. A., Thomas, A. G., McPherson, R. L., Jayabalan, A. K., Busa, V. F., Cheng, S. J., Murphy, B. A., Redinger, K. R., Alhammad, Y. M. O., Fehr, A. R., Tsukamoto, T., Slusher, B., Bosch, J., Wei, H., and Leung, A. K. L. (2022) High-throughput Activity Assay for Screening Inhibitors of the SARS-CoV-2 Mac1 Macrodomain. ACS Chem Biol

38. Capobianco, A. J., Schürer, S. C., Zhu, X., and Kelley, T. T. (2021) Inhibitors of the notch transcriptional activation complex kinase (" nack") and methods for use of the same. Google Patents

39. Frick, D. N., Virdi, R. S., Vuksanovic, N., Dahal, N., and Silvaggi, N. R. (2020) Molecular Basis for ADP-Ribose Binding to the Mac1 Domain of SARS-CoV-2 nsp3. Biochemistry 59, 2608-2615

40. Schuller, M., Correy, G. J., Gahbauer, S., Fearon, D., Wu, T., Diaz, R. E., Young, I. D., Carvalho Martins, L., Smith, D. H., Schulze-Gahmen, U., Owens, T. W., Deshpande, I., Merz, G. E., Thwin, A. C., Biel, J. T., Peters, J. K., Moritz, M., Herrera, N., Kratochvil, H. T., Consortium, Q. S. B., Aimon, A., Bennett, J. M., Brandao Neto, J., Cohen, A. E., Dias, A., Douangamath, A., Dunnett, L., Fedorov, O., Ferla, M. P., Fuchs, M. R., GorrieStone, T. J., Holton, J. M., Johnson, M. G., Krojer, T., Meigs, G., Powell, A. J., Rack, J. G. M., Rangel, V. L., Russi, S., Skyner, R. E., Smith, C. A., Soares, A. S., Wierman, J. L., Zhu, K., O'Brien, P., Jura, N., Ashworth, A., Irwin, J. J., Thompson, M. C., Gestwicki, J. E., von Delft, F., Shoichet, B. K., Fraser, J. S., and Ahel, I. (2021) Fragment binding to the Nsp3 macrodomain of SARS-CoV-2 identified through crystallographic screening and computational docking. Sci $A d v 7$

41. Friesner, R. A., Banks, J. L., Murphy, R. B., Halgren, T. A., Klicic, J. J., Mainz, D. T., Repasky, M. P., Knoll, E. H., Shelley, M., Perry, J. K., Shaw, D. E., Francis, P., and Shenkin, P. S. (2004) Glide: a new approach for rapid, accurate docking and scoring. 1. Method and assessment of docking accuracy. J Med Chem 47, 1739-1749

42. Friesner, R. A., Murphy, R. B., Repasky, M. P., Frye, L. L., Greenwood, J. R., Halgren, T. A., Sanschagrin, P. C., and Mainz, D. T. (2006) Extra precision glide: docking and scoring incorporating a model of hydrophobic enclosure for protein-ligand complexes. $J$ Med Chem 49, 6177-6196

43. Halgren, T. A., Murphy, R. B., Friesner, R. A., Beard, H. S., Frye, L. L., Pollard, W. T., and Banks, J. L. (2004) Glide: a new approach for rapid, accurate docking and scoring. 2. Enrichment factors in database screening. J Med Chem 47, 1750-1759

44. Jacobson, M. P., Friesner, R. A., Xiang, Z., and Honig, B. (2002) On the role of the crystal environment in determining protein side-chain conformations. J Mol Biol 320, 597-608

45. Jacobson, M. P., Pincus, D. L., Rapp, C. S., Day, T. J., Honig, B., Shaw, D. E., and Friesner, R. A. (2004) A hierarchical approach to all-atom protein loop prediction. Proteins 55, 351-367

46. Sastry, G. M., Adzhigirey, M., Day, T., Annabhimoju, R., and Sherman, W. (2013) Protein and ligand preparation: parameters, protocols, and influence on virtual screening enrichments. J Comput Aided Mol Des 27, 221-234 
A

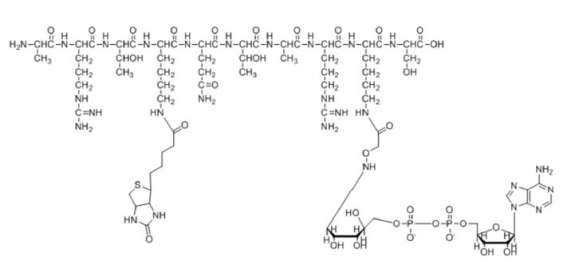

Peptide 1: ARTK(Bio)QTARK(Aoa-RADP)S Peptide 2: 5Flu-ARTKQTARK(Aoa-RADP)S Peptide 3: ARTK(Bio)QTARKS Peptide 4: 5FIu-ARTKQTARKS

D

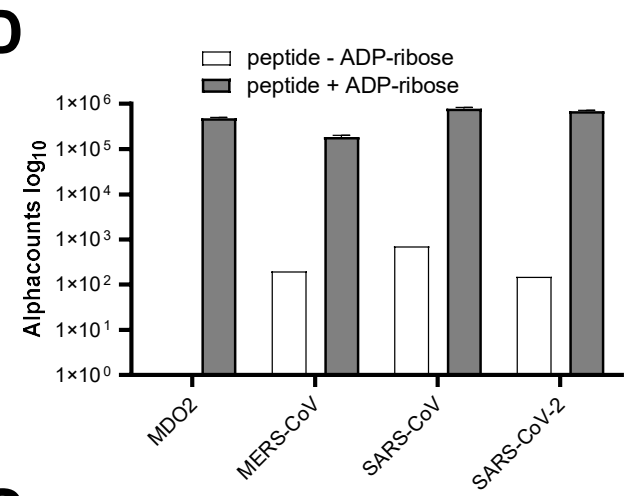

G

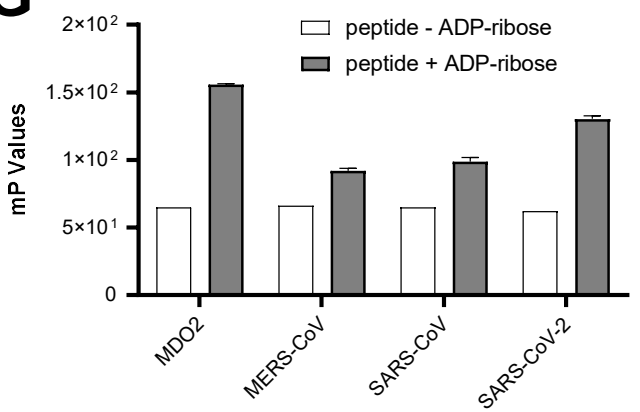

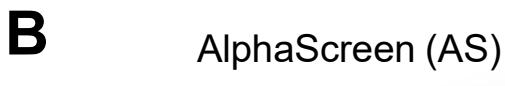

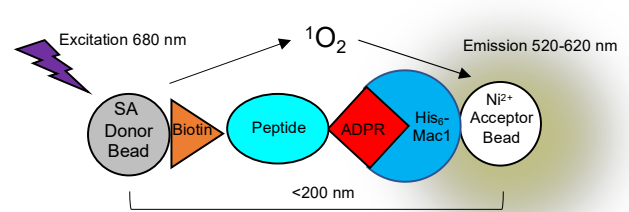

E

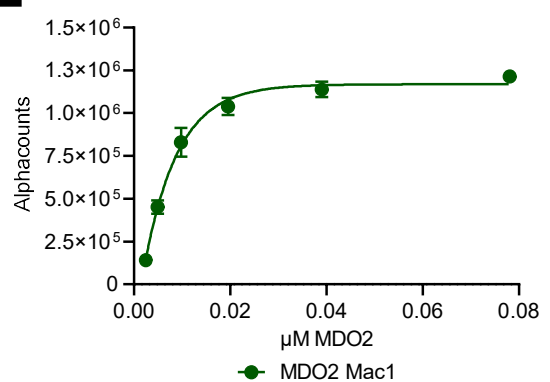

H

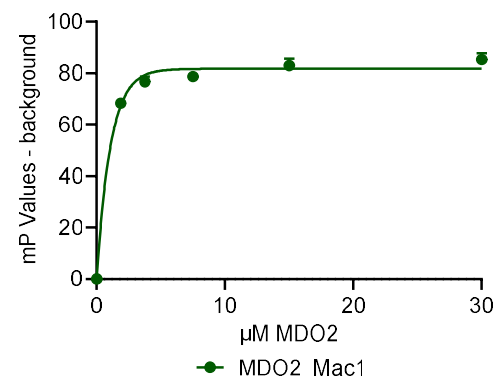

C Fluorescence Polarization (FP)

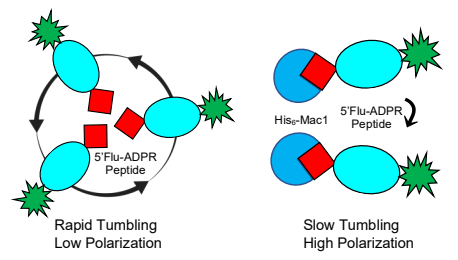

$\mathbf{F}$

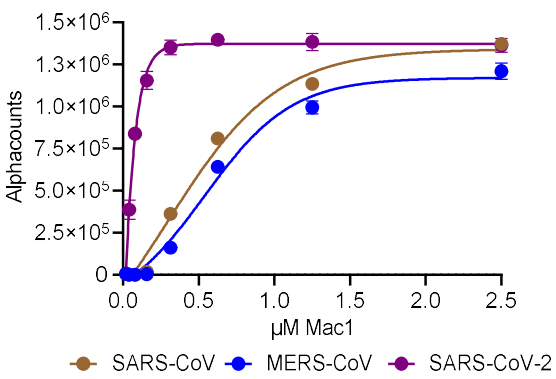

\section{I}

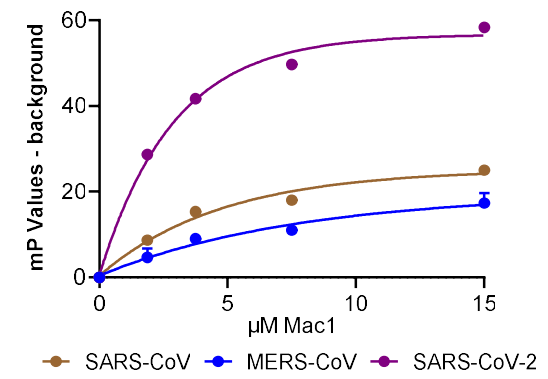

Figure 1. Coronavirus Mac1 binding to ADP-ribosylated peptides. A) Illustration of the amino-oxyacetic acid modified lysine-conjugated ADP-ribosylated peptide with an additional biotin conjugated to a different lysine residue and included are the amino acid sequences and modification sites of peptides used in this study. B-C) Cartoon diagrams depicting a bead-based AS (A) and FP (B) assays for measuring macrodomain interactions with an ADP-ribosylated peptide. D) Macrodomain proteins were incubated with peptide \#1 or peptide \#3 for 1 hour at RT and Alphacounts were determined as described in Methods. E-F) Peptide \#1 was incubated with indicated macrodomains at increasing concentrations and Alphacounts were measured as previously described. G) Mac1 proteins were incubated at indicated concentrations with peptide \#2 or peptide \#4 and the plate was incubated at $25^{\circ} \mathrm{C}$ for $1 \mathrm{hr}$ before polarization was determined. H-I) Peptide \#2 was incubated with indicated macrodomain proteins at increasing concentrations and polarization was determined as previously described. All data represent the means \pm SD of 2 independent experiments for each protein. 

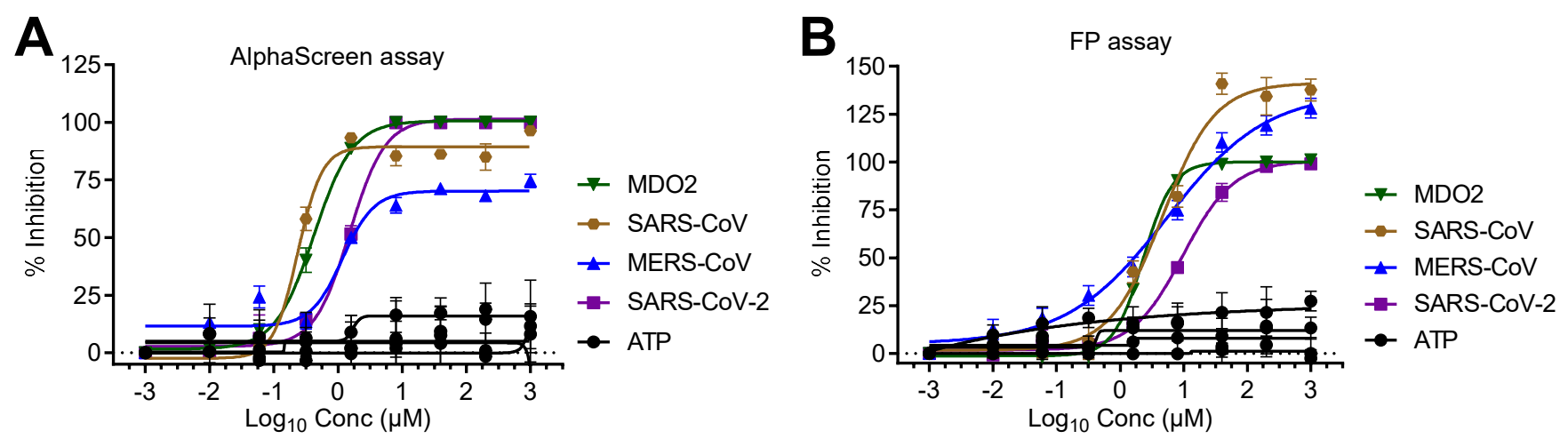

\begin{tabular}{|c|c|c|c|c|}
\hline AS assay & MDO2 & SARS-CoV & MERS-CoV & SARS-CoV-2 \\
\hline $\mathrm{IC}_{50}(\mu \mathrm{M})$ & $0.42 \pm 0.05$ & $0.24 \pm 0.03$ & $1.25 \pm 0.23$ & $1.5 \pm 0.05$ \\
\hline
\end{tabular}

\begin{tabular}{|c|c|c|c|c|}
\hline FP assay & MDO2 & SARS-CoV & MERS-CoV & SARS-CoV-2 \\
\hline $\mathrm{IC}_{50}(\mu \mathrm{M})$ & $2.3 \pm 0.02$ & $4.6 \pm 0.44$ & $5.4 \pm 0.33$ & $9.74 \pm 0.75$ \\
\hline
\end{tabular}

Figure 2. Free ADP-ribose inhibits macrodomain binding to ADP-ribosylated peptides. ADP-ribose competition assays were used to block the interaction between macrodomain proteins and ADP-ribosylation peptides in the AS (A) or FP (B) assays. ATP was used as a negative control. The data represent the means \pm $\mathrm{SD}$ of 2 independent experiments for each protein. 
A

\begin{tabular}{|c|c|c|}
\hline Library & Type of compounds & \# of Compounds \\
\hline Maybridge Mini & Drug-like Diverse Scaffolds & 2,000 \\
\hline Analyticon & Natural products & 4,196 \\
\hline 3D BioDiversity & Bioactive scaffold-based diversity & 19,528 \\
\hline Peptidomimetics & Peptide structure mimetics & 12,139 \\
\hline \multicolumn{2}{|c|}{ Total \# of compounds } & 37,86 \\
\hline
\end{tabular}

C

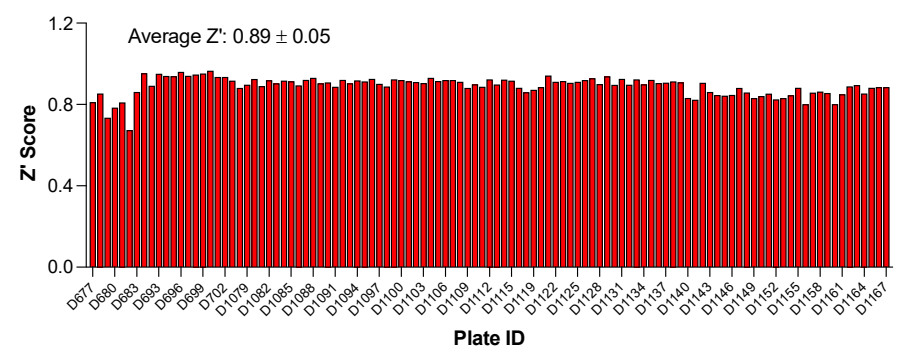

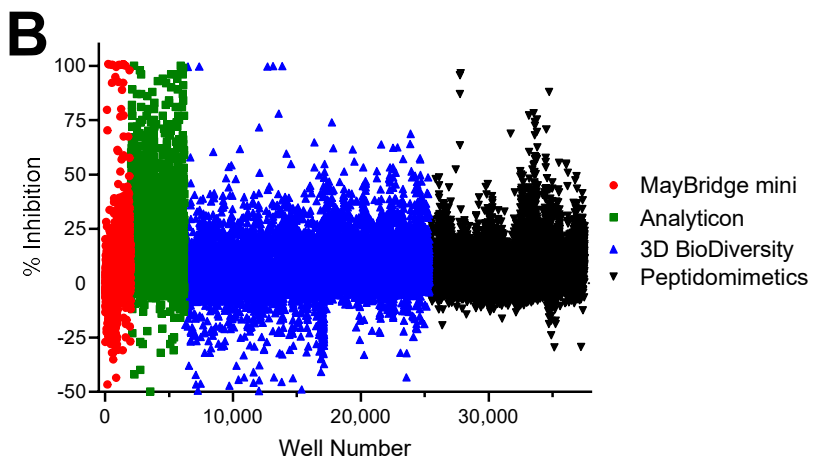

$\mathbf{D}$

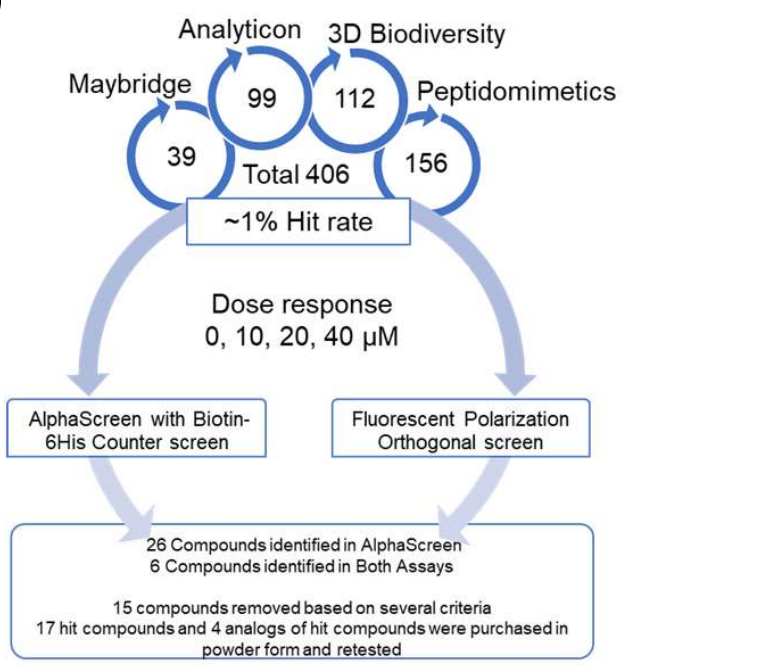

Figure 3. High-throughput screen for SARS-CoV-2 Mac1 inhibitors. A) List of libraries that were screened, the number of compounds from each library, and the type of compounds each library contains. B) Scatterplot showing the \% inhibition of each compound in the screen. The cutoff for a hit was the plate median +3 standard deviations. C) Z' scores were determined for each plate in the screen. The average Z' score was $0.89 \pm 0.05$. D) Dose response confirmation. From the original screen, we identified 406 potential hits, these hits were retested in a dose-response assay on both the AS and FP assays and were also counterscreened against a biotinylated 6His peptide. After these assays and other exclusion criteria, 17 hit compounds and 4 analogs were repurchased or resynthesized. 
A

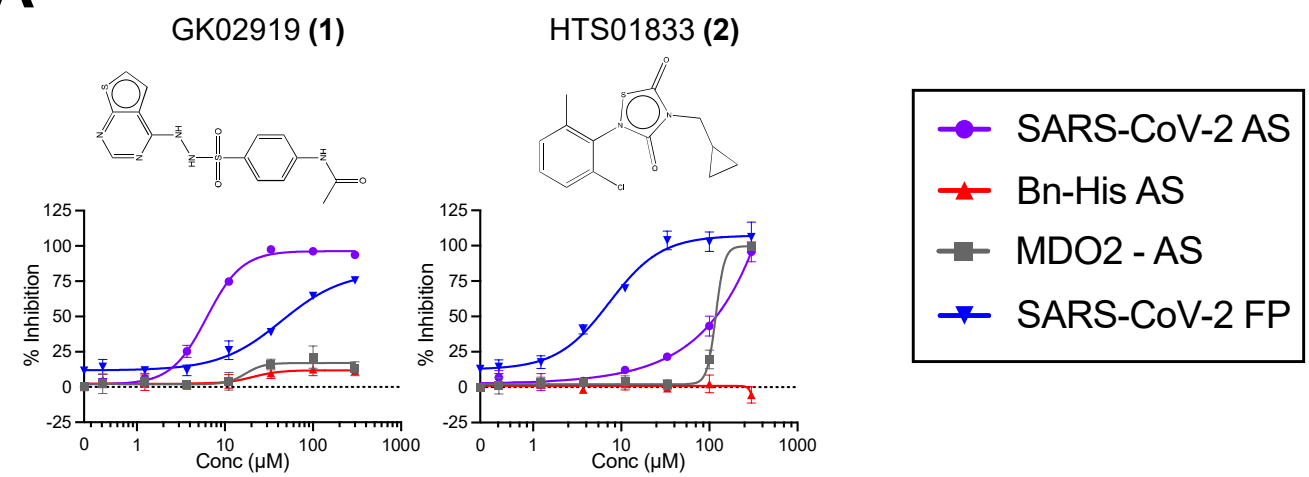

B
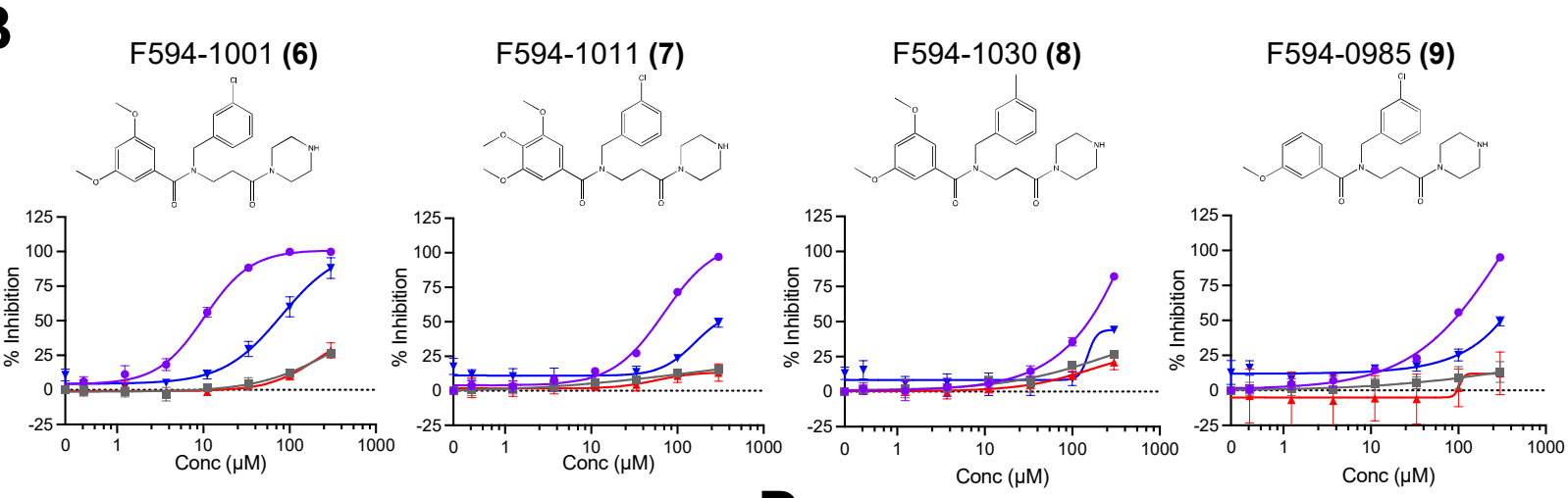

C
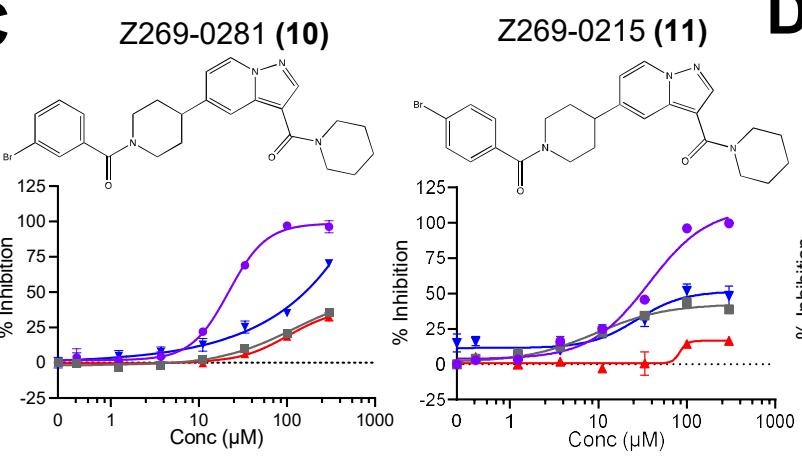

D
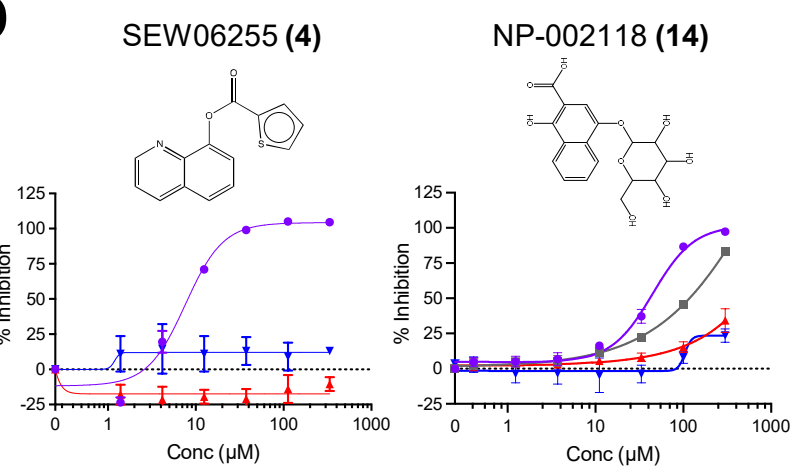

Figure 4. Identification of chemical compounds that inhibit SARS-CoV-2 Mac1 ADP-ribose binding. Dose-response curves representing hit compounds identified in the HTS. A) Maybridge Mini Library compounds 1, 2. B) Compound 6 and its analogs, 7, 8, 9. C) Compound 10 and its analog 11. D) Compounds 4 and 14 which did not inhibit FP assay. Data represent the means \pm SD of at least 2 independent experiments for each protein. Structures were created using ChemDraw. 
bioRxiv preprint doi: https://doi.org/10.1101/2022.03.01.482536; this version posted March 2,2022 . The copyright holder for this preprint (which was not certified by peer review) is the author/funder. All rights reserved. No reuse allowed without permission.

Table 1: IC $\mathrm{C}_{50}$ of the selected compounds in AlphaScreen and Fluorescence polarization assays

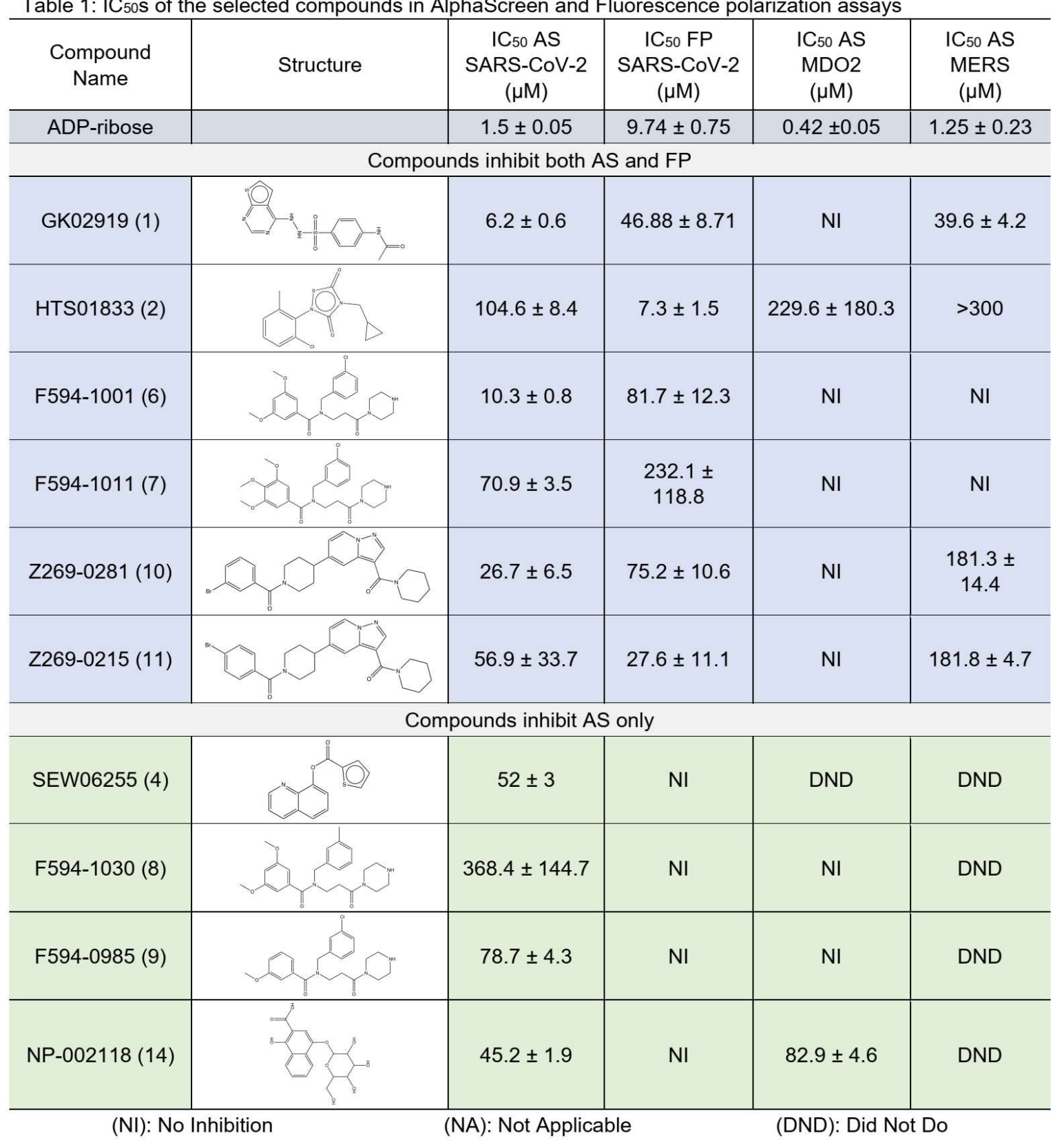


ADP-ribose

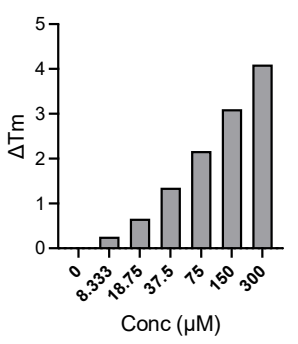

6

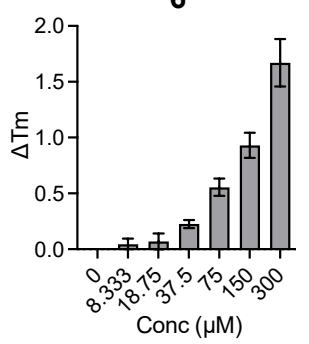

ATP

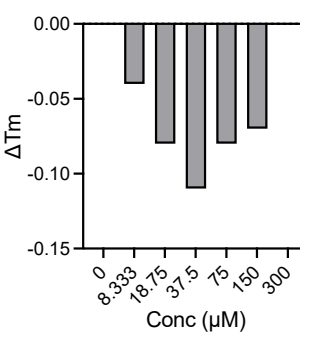

7

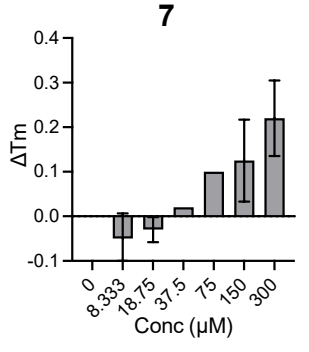

1

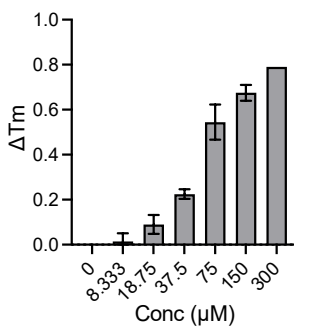

10

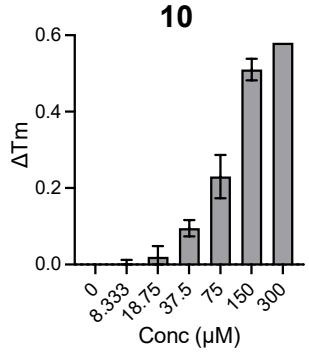

2

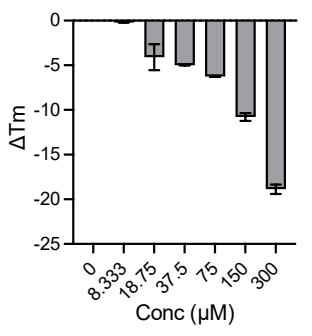

11

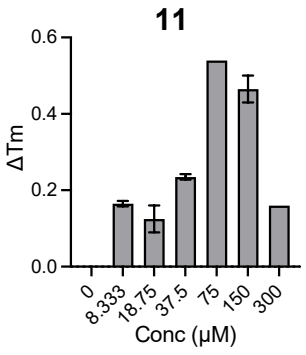

Figure 5. Thermal stability of SARS-CoV-2 Mac1 after incubation with hit compounds. The top 6 hit compounds were tested for their ability to increase the thermal stability of SARS-CoV-2 Mac1 in a differential scanning fluorimetry assay (DSF). The data represent the means $\pm \mathrm{SD}$ of the $\Delta \mathrm{T}_{\mathrm{m}}$ from two independent experiments. 
Table 2: Peak values of DSF thermal shift temperatures

\begin{tabular}{c|c|c|c|c|c|c}
\hline & \multicolumn{6}{|c}{ Peak $\Delta \mathrm{Tm}$} \\
\hline Compound & $\mathbf{1}$ & $\mathbf{2}$ & $\mathbf{6}$ & $\mathbf{7}$ & $\mathbf{1 0}$ & $\mathbf{1 1}$ \\
\hline Average & 0.68 & $18.88-$ & 1.67 & 0.22 & 0.51 & 0.47 \\
\hline SD & 0.04 & 0.53 & 0.21 & 0.08 & 0.03 & 0.04 \\
\hline Conc $(\boldsymbol{\mu M})$ & 150 & 300 & 300 & 300 & 150 & 150 \\
\hline
\end{tabular}


A

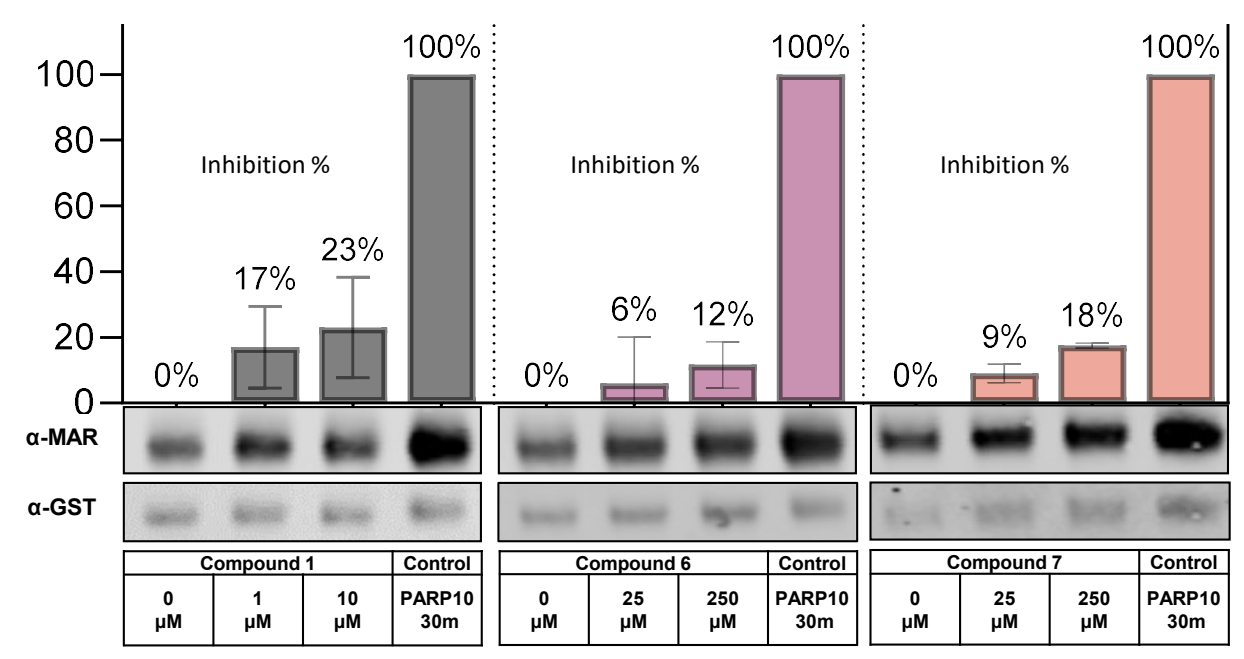

B
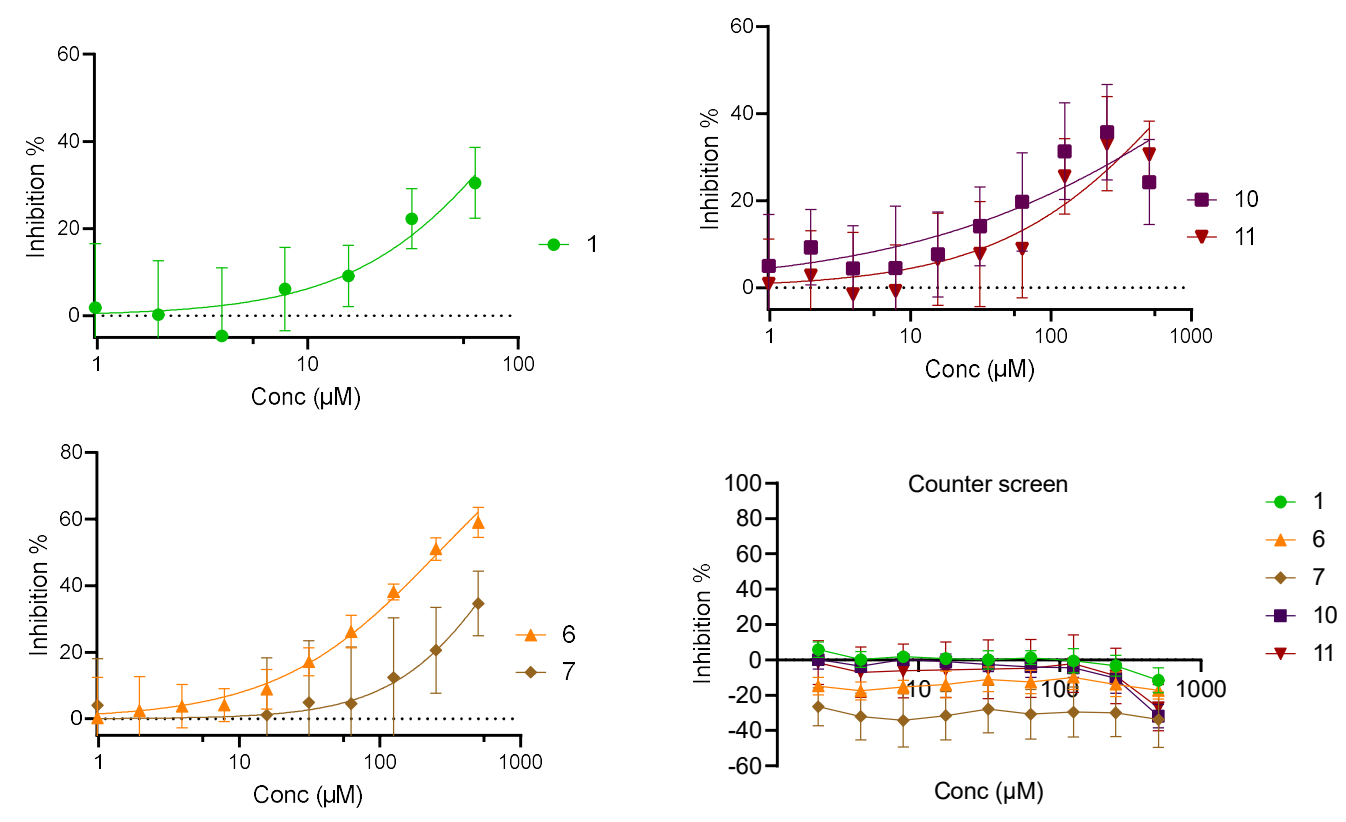

Figure 6. Impact of hit compounds on SARS-CoV-2 ADP-ribosylhydrolase activity. A) Compounds were incubated at indicated concentrations for 30 minutes with the SARS-CoV-2 Mac1 protein prior to adding the PARP10 substrate and then were further incubated for 30 minutes. Proteins were analyzed by Immunoblotting with anti-GST (PARP10) and anti-MAR binding reagent (MABE1076). Gels were quantitated using Image Studio software. The bar graph above each immunoblots represent the mean inhibition \pm SD from at least two independent experiments. 
A

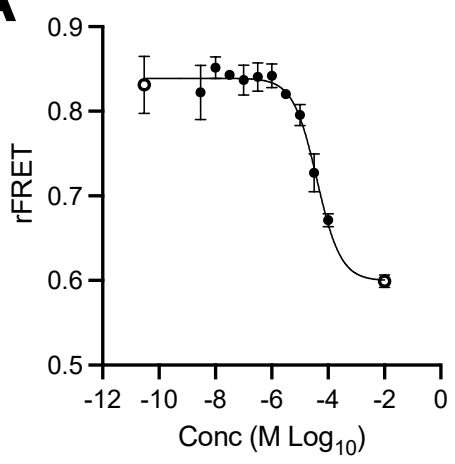

B

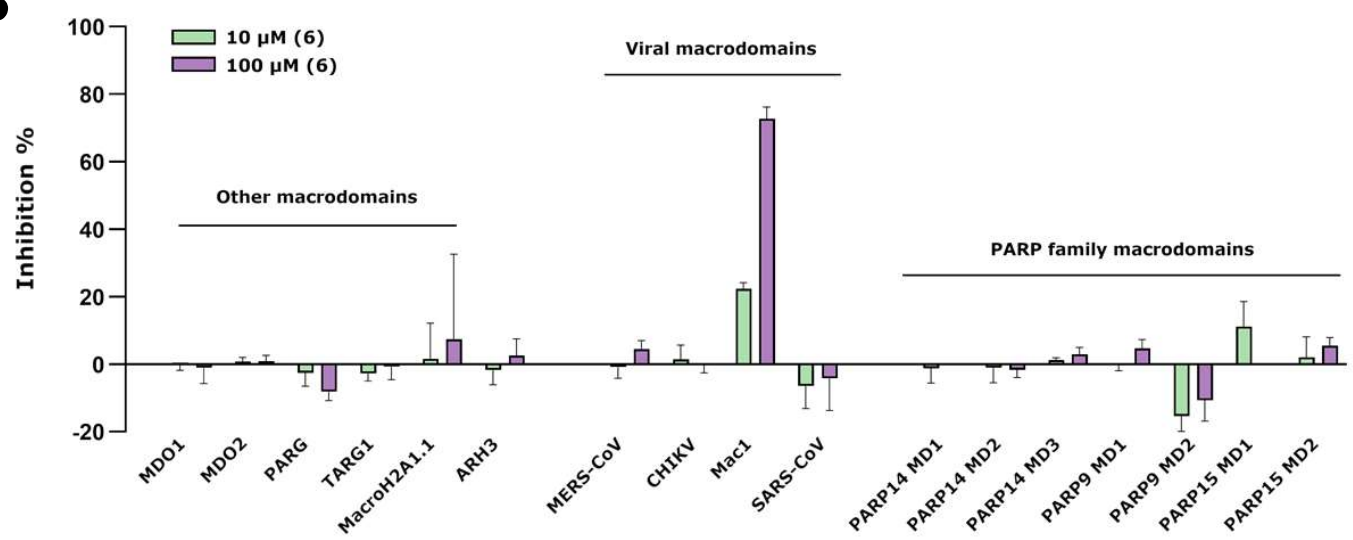

Figure 7. Compound 6 is highly selective for the SARS-CoV-2 Mac1 protein. A-B) Compound 6 was tested in a FRET-based assay for its ability to inhibit SARS-CoV-2 Mac1 protein in a dose-dependent manner (A) and for its ability to inhibit a panel of 17 macrodomain containing proteins (B). The data in means \pm SD are shown as a single experiment representative of 3 independent experiments. 

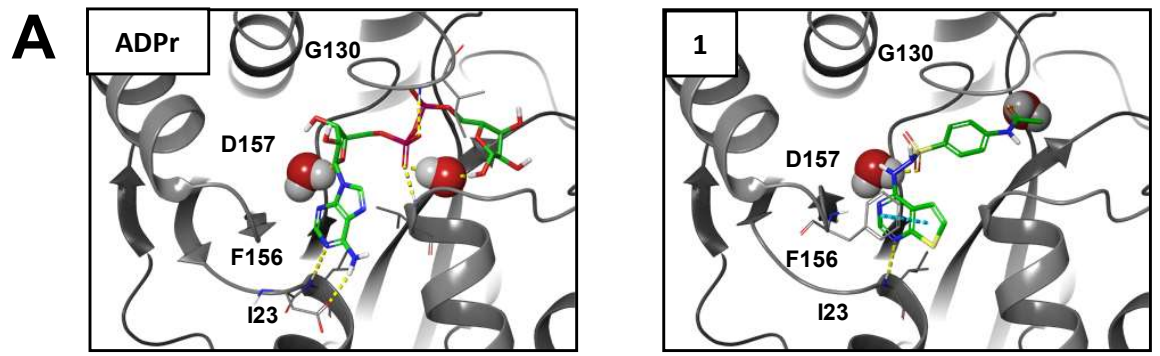

B
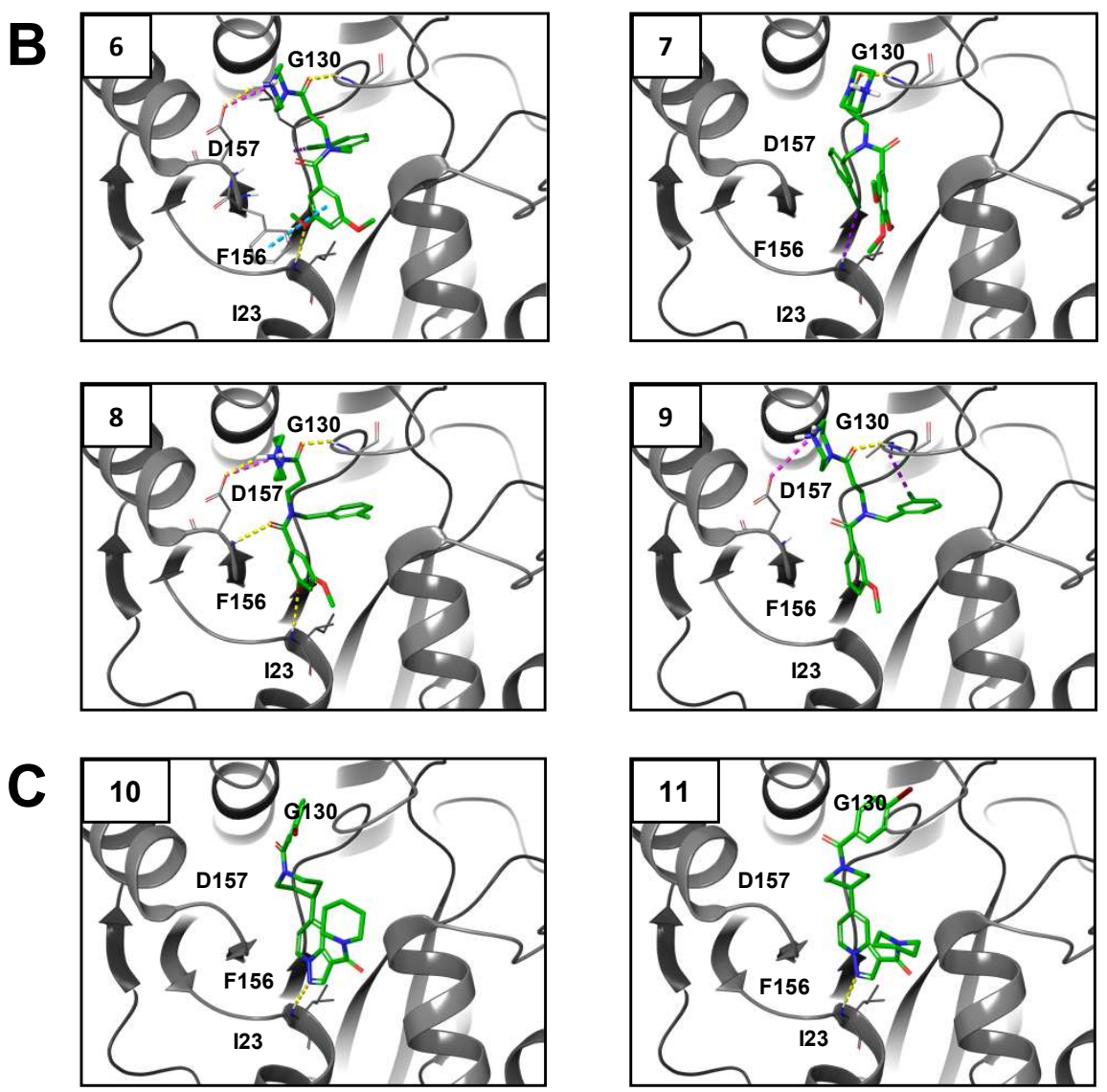

Figure 8. Computational modeling of identified compounds with SARSCoV-2 Mac1 structures. Indicated compounds were docked and modeled with SARS-CoV-2 Mac1 structures using Maestro Schrödinger software and separated into 3 groups. (A) - Compound 1; (B) Compounds 6, 7, 8, 9; (C) Compounds 10, 11. Yellow lines - hydrogen bonds; Cyan lines - pi-pi interactions; magenta lines - weak hydrogen bonds; and purple lines halogen bond. 
bioRxiv preprint doi: https://doi.org/10.1101/2022.03.01.482536; this version posted March 2, 2022. The copyright holder for this preprint (which was not certified by peer review) is the author/funder. All rights reserved. No reuse allowed without permission.

Table S1: Compound docking scores

\begin{tabular}{cccc}
\hline $\begin{array}{c}\text { Compound } \\
\#\end{array}$ & docking score & $\begin{array}{c}\text { glide } \\
\text { emodel }\end{array}$ & Mac1 Structure \\
\hline 1 & -7.857 & -81.695 & 6 WOJ \\
6 & -4.563 & -50.414 & 7RKO \\
7 & -3.338 & -34.249 & 7RKO \\
8 & -4.064 & -57.015 & 7RK0 \\
9 & -4.287 & -61.816 & 7RK0 \\
10 & -4.806 & -59.941 & 6 WEY \\
11 & -5.306 & -58.757 & 6 WEY \\
\hline
\end{tabular}



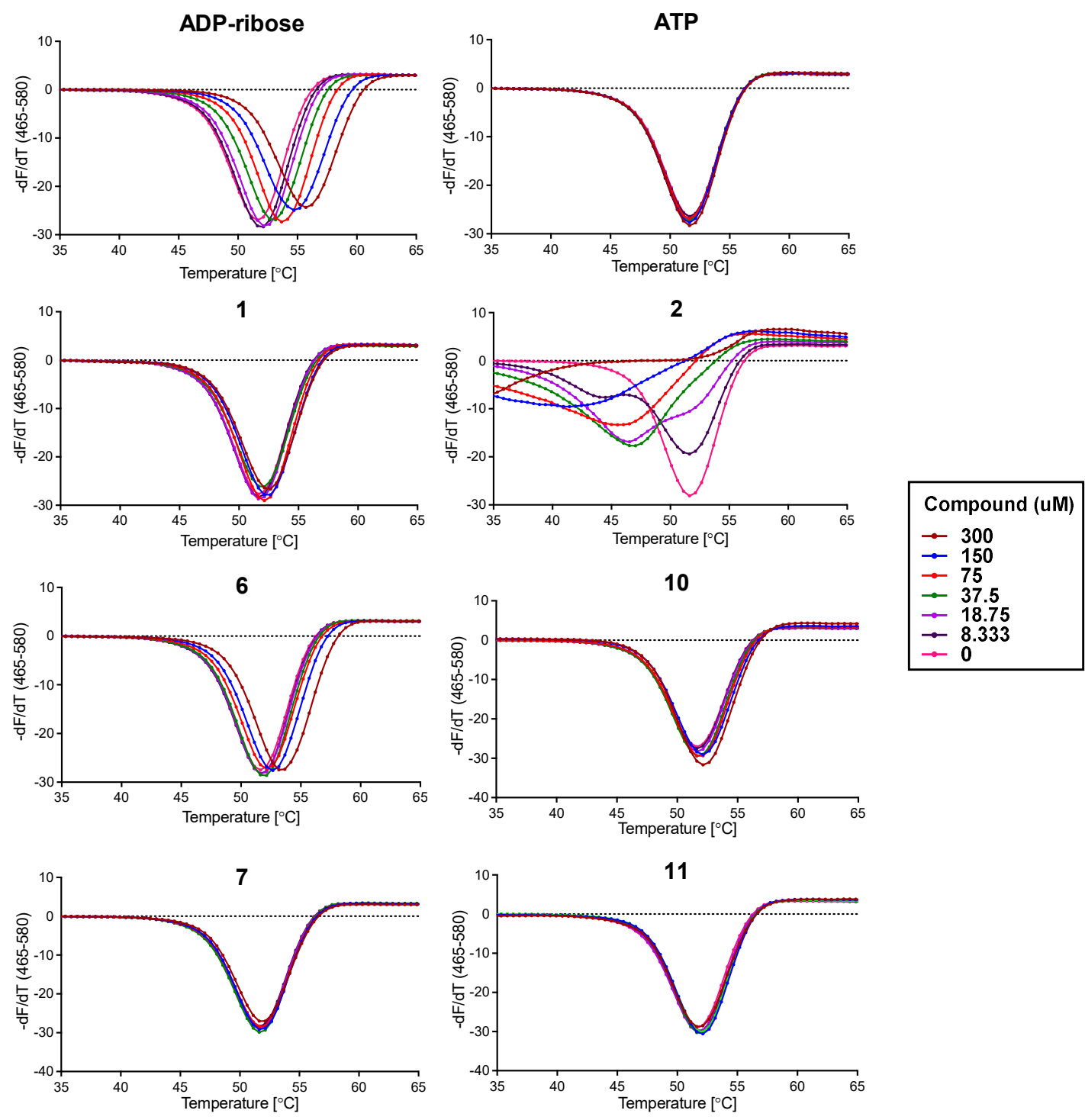

Figure S1. Thermal stability of SARS-CoV-2 Mac1 after incubation with hit compounds. The top 4 hit compounds were tested for their ability to increase the thermal stability of SARS-CoV-2 Mac1 in a differential scanning fluorimetry assay (DSF). Thermal profiles are shown for each compound at different concentrations. $I$ 

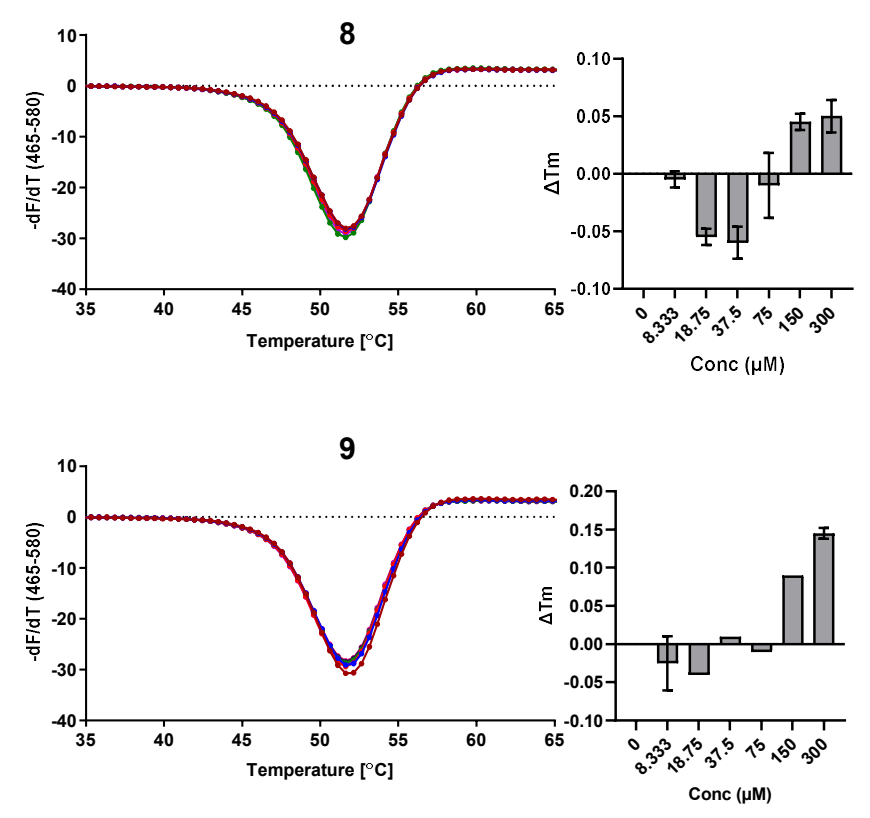

Figure S2. Thermal stability of SARS-CoV-2 Mac1 after incubation with analog compounds. Two analogs of FS2MD-006 are shown here for their ability to increase the thermal stability of SARS-CoV-2 Mac1 in a differential scanning fluorimetry assay (DSF). Thermal profiles and change in $T_{m}$ are plotted for each compound at different concentrations. 